Andrews University

Digital Commons @ Andrews University

1965

\title{
The Relative Efficacy of Selected Drugs Upon the Physical Activities and the Attention Span of a Ten Year Old Brain- Damaged Child
}

Ruth Elaine Atkinson

Andrews University

Follow this and additional works at: https://digitalcommons.andrews.edu/theses

Part of the Chemicals and Drugs Commons, and the Psychiatry and Psychology Commons

\section{Recommended Citation}

Atkinson, Ruth Elaine, "The Relative Efficacy of Selected Drugs Upon the Physical Activities and the Attention Span of a Ten Year Old Brain-Damaged Child" (1965). Master's Theses. 154.

https://dx.doi.org/10.32597/theses/154

https://digitalcommons.andrews.edu/theses/154

This Thesis is brought to you for free and open access by the Graduate Research at Digital Commons @ Andrews University. It has been accepted for inclusion in Master's Theses by an authorized administrator of Digital Commons@Andrews University. For more information, please contact repository@andrews.edu. 


\author{
Androws Dhiverst ty \\ School of Craduate Studites
}

THE RELATVE BWICICY OF SELZCTED DRWaS UPOH THE

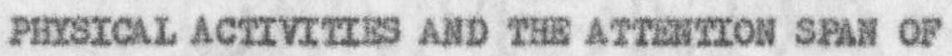

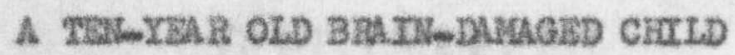

\author{
A Thesis \\ Presented in Partial Rulfijinent \\ of the lequatrensents for the Degree \\ Hastor of Arts
}

by

Nath Kaine Atidinson

Mtany 1965 
This thesis, written under the direction of the Chasman of the oandidate's Cuidance Comittee and approved by all members of the Comanttee, has been presented to and accepted by the faculty of the School of Graduate Studies in partial fulfillment of the requirenents for the Haster of Arts degree.

Date Mar 1965

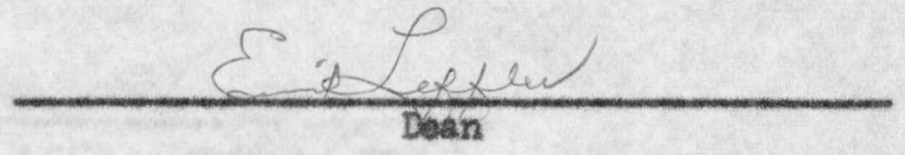

Gutdance Comat ttee
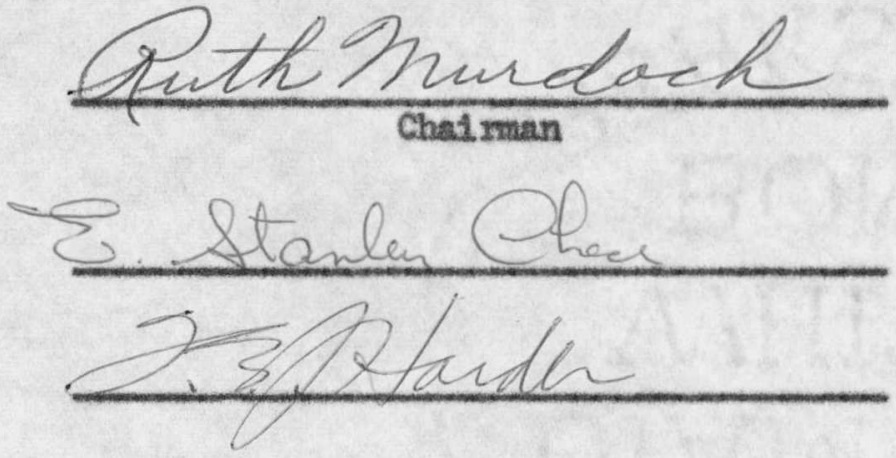


\section{PLESACS}

Mas Atlinson, working under the sidiled direction of Dr. Murdoch, has fur nished us with a series of extrenely revealing word-photographs.

These are the sevomi-hours-long, momont-by-moment acoounts of a congent talIy brain-ingured child under the influence of one experinental medication after another (at intervals of some weeks). The condstions have been waintalned as nearly constant as is practical in exporiments involving human beings.

Tho result is a valuable contribution, not only toward the evaluation of the specifle necleation under invostigetion, but also as ellnical deseriptions. As such, they gror.ily mhance our approciation of the turnoti in which the child is Iiving, and which she ongenders in all those who IIve in contact with her, not only in her home but also in the sehool and in the communtty.

Nay 17,1965

Kathorine X. Rlee, Psychiatrist

llote: The subject of this study was a patient under the care of Dr. Katherine K. Ilee at the thene the stacly was made. 
TABIS OF COWTENS

Page

Praface ....................................... 1 Itst of Firures ...............................111 Chaptex

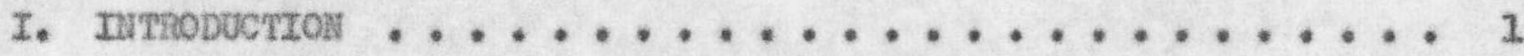
The purpose of the study .................... 1 The importance of the study .................. 1 Defintilons of torns used .................... 2 holated studtes ......................... 3 Iypothesls .......................... 6 Frocedures ............................ 7 IAmtations .......................... 8 Organization of the stucty .................. 9 II. ICLATE ITTERTURS $\ldots \ldots \ldots \ldots$

Charaterlstícs .......................... 20

Diagnosis ........................... 11 Ediucational teohniques .................... II III. PROCEDURES BOLLONID ....................... 14 IV. SOURCES, TBULATON, AKD IVTERPRENATION OF DAT ......... 17

V. ConCLUSTORS ............................ 38 APLEHDIXES , ...............................440 BIBLTOGRATI ................................. 5 ? 
Mygure

1. The totel number of alstrations recorded during flve obser vations of a ten-year old brain-damaged ohd ld ........ 32

2. The total number of contaets with people reeoxded during flve observations of a ton-year old brain-dsmaged ohild ..... 34

3. The total number of conversstions recorded daring five observations of a ten-year old brain-danagod obild ........ 35

4. The total number of nomal activithes recorded during five observations of a ten-year old breinedanaged child ...... 37 


\section{CHAPTER I}

\section{IMTnoDUcTro:}

The Purpose of the Study

The purpose of this study was to detorntine the relative efflescy of aelected drugs in reducting the hyperactivity and inoressing the attention spen of a ten-year old chlld who hsd been medteally diagnosed as having brain darage.

The evaluation of the offeots of three drugs, Chlordiasepoxd de (IAbm

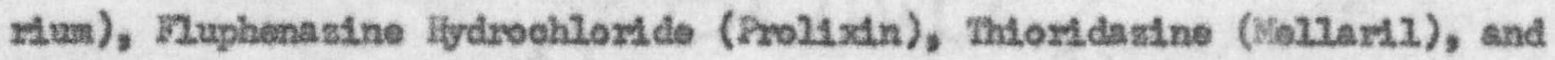
a combination of MellardI and Mothylphonidato Hydrochlorido (Rtalin), was made by a pryohtatzist after conideration of (1) written observations of the ohlld"s school sottivities during a two-hous perlod, (2) a tebulation of data besed on the observations, (3) roports macle by the parents and teacher of the ohdld, and (4) Interviews wath the aubject.

The Importanos of the Study

IIg and Ases, in thetr publucation Grld Behavior, describe braln-

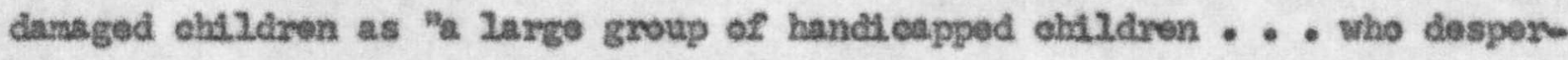
ately need ous help.n $n^{2}$ Lore and more doctors and child guldance worioers are dectaling that brain Injuxies are, in part, responatble for many learning

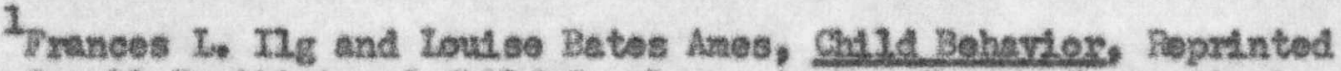
Iron the Cesell Institute of Chald Developnent, Ient Isven, Connectlcut. (Glen Miyn, Mlinols: West Suburban Assodation for tho Other Child, n.d.). 2. 
difesculties and woh mibehwior in coro ehildren.

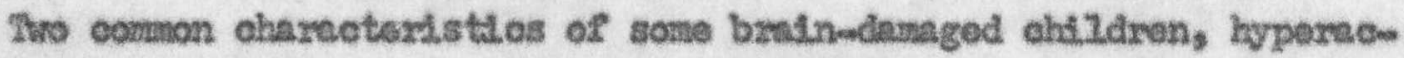
tivity and a short attention span, ${ }^{1}$ often cause atsunclorstanding about the problaxas those ehtldron have. Ary durg roductng hypexicinests and Inereasing attention span probebly would boneflt the ohlidren. Farents alight be roLeved of the andety and the feoling of soctal stl gna caused by the suggosthon that poos chdid-rearing practlees and/or insecure interpersonal relathonshtpe were the caves of thotr chlid's behavior problems. Foachors posm sibly could bo moro stacessful in Instructing these ohildren, and schoolnates probnbly would have less reason to think of these boys and glris as "afforent," The ehildren thenselves adght be less prone to develog adddthonal easotional, probleme.

This study is Important, too, because the ohdid Involved needs holp toward Itving as nomal a ILfo as posatble. The Individual"s bohavior chos the attantion of hor fandly, her taschors, and hor sssociates. Because It was so abnormal, nodleal and psychologlcal holg were sought for her. The

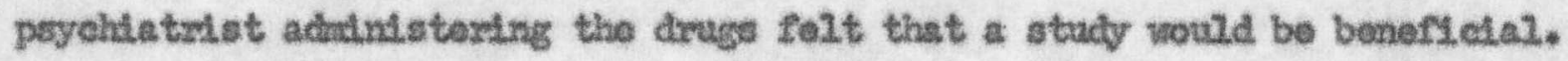

Insemuch as 13 ttle controlled experinontation has been tone in this arca, the study is potentialiy stgafleant. It might be indieative of rutwo holp for the Individuals sufforing from bratn damago and those nost directly concesned wh holptng theat.

\section{Dofint thons of Temas Used}

Inloss othorwise nontioned in this peper, the following teras and defunttons are used.

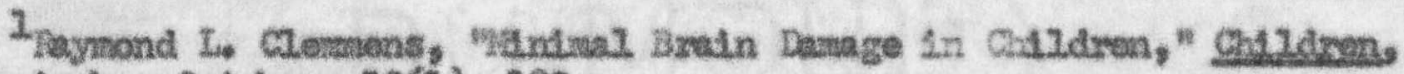
vrI (Septembenootober, 196i), 180. 
Bnin Danage of Brin In fuw

Any hann to the brain which affocte the child's abilsty to funothion as a nomal individual is brain danage. The individual's intellectual, motor, behaviorel, and/or sense funetions have been inpeired or altered because of the inproper funetioning of the central norvous systoas.

Hvertinests or livmenetivity

Aypericlneads is exhiblted by a ohtld who seens to be in constant notion. The Individual appears rostless and fldgety and seems dyiven to mothon.

X. C.

For the purgoses of this study, the instiels M. C. sue used to refer to the oldild involved.

Zneobe

A placebo is an inactive medicine given oi ther to satilefy a pathent"s destre for medication, or as a control, for purposes of comparison In stadying the effect of othor medieations.

Perchotropie Dreses

Substanees capable of influeneing pryohologloal and mental processes and of modifying human enotions and bohavior are called psychotrople drugste ${ }^{2}$

Roleted Studies

The amount of research avallable on this spectrie tople is extreaely

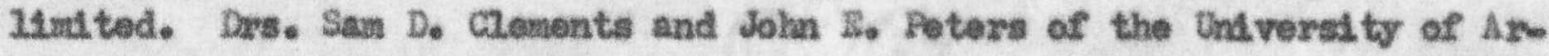
kanses Hedical Center state that their extensive work wh th brain-damaged

1.P. J. Doyle, "The Organie Elyporklnotise Syndrome," Joumal of Sobool Fasth, XxxII (Ootober, 1962), 301. 
children is founded upon "olinical research and expexience and is not yet. based on earefuliy controlled experimentation. "it The doctors continue:

Wo have found that a surpmiaing and significant munber of our mintmal brain dysfunetion (MBD) osses can be handled by a combination of drugs and Infrequent counselling. The drugs we have found most helpfur in reciueling hypereoti vi ty and 1mitability, and in inereasing attention span are oaptodlane (Suvren), and thioxidagine hydrochlorido (Mollari2), and the amphotanines. We have not made extensive use of phenothiazines other then thioridazine. Other clinies have reported favorably on several of then in the treatment of hyperkinesis in ohildren. ${ }^{2}$

Artina and his comoricers "found that thioridandne Hellaxil is offective meiniy in combating psychomotor hyperactivity and excitation. ${ }^{3}$

Dr. Kinross-Wright treated one-hurdred ninety-elght patients, in-

eluding forty-one with acute funetional psychoses and twenty-five with brain syndromes. NeIlaxll was the drug most liked by patlents because of the fow side effects. ${ }^{4}$

Sandoz Fharmaceuticals, Ino., states that Wellaxil thiordiagine is eminently effective in reducing exol tement, hypormotility, abnormal inithative, affective tension and agitation through 1ts inhibitory effect on psychomotor funetions " $^{5}$ The drug is recommended by the coupany for use with ohlidren exhtbiting hyperactivity.

In 1961 Cleumens reportad that:

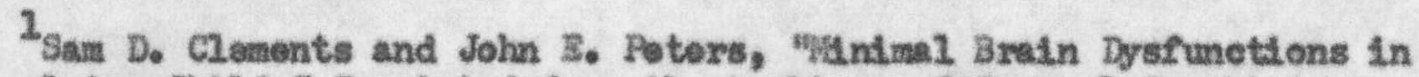
the sehool-aige Chtld," Reprinted from the Arohives of General Psyohiatry, VI (Mareh, 1963), 18 .

\section{Ibid., 25.}

3uThe oxidazine in Nental Syndromes," The Joumal of the Anerican Medieal Assootation, CLXKCI (February 6, 1960), 591.

${ }^{4}$ John Kinross-Wiright, wewer Phenothiazine Drugs in Treatment of Nervous Disorders," The Journal of the Aneriean Medical Assoeilation, CLXX (July 11, 1959), 1283-1288.

Sandoz Pharmaeeuticels, Division of Sandoz, Ince, Information Shoet on Kollaril, Hanover, New Jersey, Juity 12, 1963. 
Drug therapy has been of st gmifloant value in deorvasing the hyporactivity, distractibility, and extreane andety sasocieted wi th brain inJury. Vany pharmacologle agents have boon used. Bhoouraging and at thines dramatic results have been obtained with dextromsmphetamine, bensdiryl, and notably, dilantin. 1

John $T$. Ferguson and associates write that "the psyehoanaleptle acm thity, or stimulsting activity on the contral nervous systom, of orally admindatered mothylphend dste (Rtalin) kydrochlorlde is well documented clini$\operatorname{call} 2 y \cdot *^{2}$

Bsenberg describes a study he and Conners made velng methylphentdate and a placebo. They evalunted systomatic responses and psychologleal. test performances (Ineluding $\mathrm{IQ}$ and Impulsivity tests) in disturbed ahdidren fron a residential trestment eentex. The experinenters found that "anong youngsters of nomal or superlor test intelligence, no drug effects wero obtalned. - . There were suggestions of improvenent in learning in the ohil. dren on methylphenidate, but the results wore equivooal. "3 The authors conelude:

The basie intelleotual liatation in mental derlolency as well as the underlying psthologie lestons in ohronte brain symdromes are not nodifiable by any known medieations. But lyperldinesis and distroct1bility, the most disturbing symptoms in these patients, froquently ean, be relieved by stluniants such as dextroanghetand or orothyiphenidate. 4

Risenberg"s study t Johns Bopletns thiverst ty School of Hodleine Involving the wae of weprobandte, prochlorperazine, and a placebo in treating hypericinetie children revealed that none of the dirugs were satlafaetory in

\section{$1_{\text {clemsens, }} 181$.}

2John I. Ferguson, et. el. Wethylphenide to (Fatalin) Hydroehlorlde Parenteral Solution," The Journal of the Amextean Nedical Assoctation. CLXII (Doceraber 2, 1956), 1303.

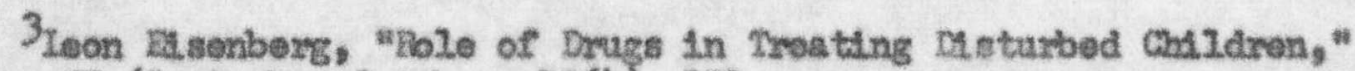
Children, XI (Septerber-Ootober, 1964), 17 .

4 Ioid. 
causing pationt improvement, 1.e., reduced hypersotivi ty. ${ }^{2}$

In discussing Ldbrium the Council on Drugs of the American Medical Association mports that it thas sone degree of effectiveness in musculoskeletal disorders associatod w1 th enotional disturbances but littlo or no offect upon those of a purely organte nature. $n^{2}$

Doyle writes that the evaluation of the use of psychotropic drugs "In hyperectswe school ehildron has not been very successful becuse of the confusion concerning theil use and because of incomplete, uneoordinated reporting $e^{3}$

Although a number of studies have been made using drugs to treat disturbed patients, few have dealt with the spectele problen of hyperidneas and a short attention span in brein-damaged children. Strallos omploying the drugs being used in the prosent investigation revealed that the medications generally wore ineffective in algnifleantly roducing hypersetivity and/or Inereasing attention span, though adnithedly improvenent was notod in some patients. In the studies oited, Mollaxil was the drug producing the groatest destrable change.

\section{Fypothesis}

The hypothesis to be tosted by this study is: That there is no significant difference in the officacy of the selected drugs in reducing phystcal activity and inereasing attention span in a tenmyesp old brain-damaged child.

\section{${ }^{2 \text { podd. }}$}

2 "Drugs Evaluated by the Council on Drugs," The Joumn of the AmerLean Yocheal Assoclatilon, CLXXXXV (July 27, 1963), 293.

$3_{\text {Doyle, } 301 .}$ 


\section{Prooedures}

The following procedures wero used in the development of the study?

1. Identifylng the problem.

2. Reviewing related studies and literature.

3. Fanning the study:

a) A psychologist on the Chiversity faculty observed the ehild and gave an Individual intelligenee test (the Wechaler Intolligence Sonle for (hildren). Arrangenents were made for Sylvis Marsh (a college student taking a course in ohlid growth and development, 1963-1964) to propare a continuous record of the child's sohool setivitles during the morning of December 12, 1963, and to make a case study.

b) Upon the basis of the information gathered, the psychologist referred the fandly to a psychiatrist. The case study, along with H. C.'s school records, and the record of the WISC was made avaslable to the psychiatrist. A medicel exandination, including an electroencephalograx, was given. After consideration of all the data, the ohild was diagnosed as boing brain-damaged.

4. Gathering pertinent data from the ease study, school records, and the ohild"s parents and teschers.

5. Consulting with the poyehiatzist. It was doelded to adainistor different medications to detemine thed $r$ effect, since experience has shom, repeatedly, that there are great variations in response to the nower ataractlos, nomalizers, and sedatives anong patients showing surprisingly sidilar pethology. The drugs librium, Frolixin, Nellaril, and a eoabination of ratalin 
and Nellaril were selected for use in this study. After the pattiont had been on each medication, a detalled record was made of every activity the child perfomed during the two-hour perlod from ten o'clock unts] noon on a school day. A rest perlod with no drug was plarmed between esch of the mediestions used.

6. Ramning the tabulation of data gathered during the obsorvathons.

7. Struoturing the fom on which to tebulate material. ${ }^{1}$

8. Naking the gutde for the data tabulation. ${ }^{2}$

9. Tabulating the data collected during each two-hour observation. 3

10. Prepazation of ber sxaphs to 1llustrate tabulations.

11. Interproting the data."

12. Draving concluslons.

\section{Is ind tations}

Though efforts were made to minindze lindtations, the following ones are recogatzed:

1. The observers" lack of training probably alde the observatifons less reliable and more inconststant than those of treined persomel would have been.

2. Posstbly more observations, longer observations, and/or a difference in the timing of the observations would give different rosults, though this does not sees 14 kely insofar as the conclum

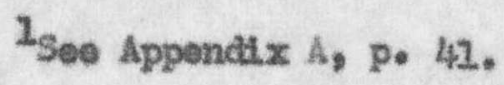

${ }^{2}$ See Appendix B, pp. $42-4 / 4$.

S See Appendires $C$ and $D_{9}$ pp. 45-53.

4 See Appendi sos $E_{,} F$, and $G$, pp. $54-56$. 
sions dram from this study are in agrement with the ingrosslons of teachers and parents.

3. A different spacing in the administration of the drugs and difforent dosages might lead to different results.

4. The varlations in the lengths of time between the Initial use of aach drug and the date of the corresponding observation may affect the velldity of the comparative results.

5. Conelueions drawn from these tests are limitod to the subject of the study.

In spite of the linitations which have been enumerated, the study does contribute toward holping $M_{0} C_{\text {. }}$ by shoving the helpfulness of a specte10 drug or combination of drugs in controlling hyperldnesis, as coupered to other medioations used in the investigation. While this study concerns one Individual the findings may be of value as an indication of what further investigations inight reveal. It points out the lack of studies in this area and olarifles the need for further researoh.

\section{Organization of the Study}

Chapter I Identifles the problem and Its 1mportanee, and states the hypothests to be tested.

Chapter II reviews 21 terature pertinent to the study.

Chapter III shows the procedures followed.

Chapter IV describes tha sourees, tabulation, and interpretation of data.

Chapter $\vee$ presents the conelusions drawn from the data. 
In recent years many reports have been mede conceming the braindamaged child. These usually include throe main topics: charactoristics, disgnosis, and odreational tochniques.

\section{Chamatoristios}

Acoording to Clements and Peters, ${ }^{1}$ Clemmens, ${ }^{2} \mathrm{Ig}$ and Ames, ${ }^{3}$ and Strauss and Lehtinen ${ }^{4}$ some or all of the following characteristies may be found in ehtldren ouffering frow brain infury. Symptons are listed without reference to importance:

1. Hyperidnests.

2. Impulsiveness (perhaps destruetiveness).

3. Irritability and aggrosel veness.

4. Fexseverance (ohild continues applying old material to new, in relevant si tus tions).

5. Perceptual-motor and general cooxilinstion defects.

6. Poor speech.

1.Clements and Poters, 19-22.

${ }^{2}$ Clennens, $180-282$.

$3 \mathrm{mg}$ and Ames, $1-4,7-8$.

4AIfred A. Strauss and Iaure B. Lehtanen, Bsyohopatholory and BAluesthon of the Broin-Infured Child (Hev Yorkt Crume and Stratton, 1947), pp. $86-97$. 
7. Short attontion span and/or distractibility.

8. Spectfic lesming difficulties, 1.0., probleas with reading, writing, spelling, and art thrmetic.

9. Soctal inmaturt ty.

10. Talleath veness or an alrost complete lack of comauni cation.

11. Unselective display of affection to total strangers or a pronouneed and continued disregard of poople.

\section{Damosts}

Clements has been coneerned especially about the correet diagnosis of ehildren with minimal brain dysfunetions. He foels that 1 is is imperstive that these ohsldren be carafully diagnosed in order that they may reoelve the best help posstble. In his own elinical work, Clenonts bases his diagnosis on the following ${ }^{2}$

1. A complete physical extarinetilon and history.

2. Peyohologleal ovaluation.

a) Wechaler. Intenligence Seale for Chyldren (the seattar of the scores on the varlous subtests is very important).

b) Bender Vasual Motor Gestalt (perhaps some others).

c) Standartased reading tost.

d) Poranal interviows and contacts.

0) Porikass projective and other techniques.

3. Complete neurological exalnation (may include an electroencephelograx).

Bduestion

The eduestion of brainmdaraged chlidren is recelving more and more

1 cleaents and Peters, 21-25. 
attention. Clements and Poters wrlte that "the proper sohool managenent af chlidran with minimal brain dysfunction is of extrome Lmportance. ${ }^{2}$ Host authors roport that these children ean be taught, but that they have to be taught in a spectal ways therefore "the teacher and the principal should lnow the chlid's diagnosis and that a progran of trostanont has been begun. " 2 The centrel concern in the echoational program for the brain-daraged ehild must be an understanding of his funetional disablittles. ${ }^{3}$ The teaching prow gram has to be geared to the chtld"s specifle defletts and must allow for a slower pace in scquiring lonowledge in those aroas. The brain-injured child any have more than average eapact ty in other areas. These ohlidren frew cuently have far greater than average perception and mosory for spatial row Iationships.

The task of loarntng is extruordinaxly difficult because of the child's restlessness and his inability to excolude 1 melevant sensory impressLons. 4

Sone of these children should bs in spectal, elassrocms in order to have a less stimulating ervinonaent. Partitions in the roon may be helpful. Every 1 ton not essentlal to the classroom operatton should be axdted. Teaching atds shovid be stmple. Devices used in an ordinary classroom should not be used because of the dilstractions they provide. Even the teacher"s dress should be vary simple and unadorned. 5

1clenents and Paters, 26.

2 mid.

3arl C. Gamison and Dewey G. Foree, The Prychalosy of Breentionel Chtldren ( $d$ d ed.; llew York: lionald Press Co., 1959), p. 363.

${ }^{4}$ Clexrsens, 180.

5Strauss and Lehtinen, pp. 127-146. 
Ig and Ames report that these ehildron "husually loam quiekiy material that is clearly structured and brought into foous for them. ${ }^{1}$ Instruethon must be in utmost reality and should be given step by step. OrdinariIy, freedon to make cholees should not be given. A more diffleult task should be attompted only when the preceding one has been eampletely masterod. Axl thmetto should be taught strueturally and reading "needs to be taught phonetically when the child is roacy to absorb this method. ${ }^{2}$

Some of these eldidiren whose grade placement is well beyond their reading level, should have a large part of their lessons read to thom so that they vili not fall behind in the informational part of their courses, 3

Oral. examinations probably $w 111$ be more accurate in getting an appraisal of the ohild's lmovledge.

A hopoful note concerning the eduoation of these chlldron is that given in Chlid Behavior, "If diagnosed correctly at an early ago, the brain Injured ehild, after spending several years in a spocial elass may be transferred to a regular class and function adequately there. ${ }^{4}$

${ }^{1} \mathrm{Ig}$ and Ames, p. 4.

${ }^{2}$ pidc.

3 Clenents and Poters, 26.

${ }^{4} \mathrm{I} g \mathrm{~g}$ and Ames, p. 5. 


\section{CHAPTER III}

\section{PROCEDURES FOLIOWED}

Chaptor I 1dentlfied the problez of hyperkinests and a shortened attentton span being displayed by a ten-year old ohtld sufferlng from bralndanage. Related Hiterature was reviewed in Chapter II. Chapter III deserdbes the procedures followed in detemining the relative effectiveness of seleoted drugs in contrelling hypersotivity and Increasing attention span in a ten-yoar old brain-damaged chs.ld.

Three different druga and a combination of two of them were admintstered in order to deternine which was most effective in the case. To avold carry-over effects, a rest pexiod with no medicatton was planned between each of the drugs used.

On December 12, 1963 (before medileations were begran), the sixl was observed and a detalled account of hor activities wes writton. A cese stady was prepared from information supplied by the sohool recoxds, the ehlld"s parents and teachers, and acquaintanees of the fardiy.

Lbriua, a sedative-type drug was begun October 30,1964 . Five at1IIgrame were given four times dally. The two-heur observation of the child was rade the 9 th of llovenber, 1964. A detalled record of bex activities from ten oteloek unt11 noon was corapiled.

On the 15th of Novatber, 1964, the second drug, Frollxin, destgned to caln down the hyperactive or stimulate the hyposctive patient, was begun. One miligran two times dally vas preserlbed. The two-hour observation was 
aade Novenber 23, 1964.

Nollaril, relatod to the phenothisaine tranquilizers, and somotimes used for behavior disorders, was Intially adininistered December 1, 1964. Twenty-tive millif grans were given four times datly. The two-hour observethion was made December 9, 1964.

A coubination of Ritalin, a mild cerobral stimulant which has soaetimes been paradoxically useful with hypoldnetic and hyperkinetic ohlidren, and Nellaxil was started January 13, 1965. After breakfast and aftor lunch, ten allilgrans of IAtalln were adninistered. Iwenty-five milligrans of Mellaril were given two times daily. On February 23,1965 , the observation was made.

The data classiriestion was based upon the type of activity and the nueber of ohanges of aetivity recorded during the flve observation periods. A longer attention span would be indileated by a decresse in the mumber of changes in activity, and lowersd hyporkdnesis would be indicated by a lessening of the frequency of non-diseoted movenents.

A fom ws constructed whiloh subdivided the four mat jor categortes (distraetions; contaet with people, delibersto proximity; conversations; and nomal setivities) into twelve sections. Mlso, the ohild's activities dur Ing each of the five observation perlods were divided Into three thixty minute perlods $(20: 30-12: 00 ; 11: 00-11: 30 ; 11: 30-12: 00)$ plus the recess perlod. Stch observation was tallied on a separate forn. See Appendix A, page 42. A guide with which to do the tebulating was construeted. The gutde 14sts typical aetivities in which the ehild engaged and the classifleation designated to sach setivity. This guide was made in order that consistency could be maintained in interpreting the ohild's aetivities. See Appendix B, pages $42-44$, 
The setual tabulation of data consisted of comparing each 1 tem noted duxing an observation's three thirtymalnute pexlods and recess with the tabvilation gudde and raiding a tally mark(s) in the proper category on the form. Then the tallies were totaled. See Appendix C, pages 45-49. Bar graphs were construeted to 11lustrate this informstion.

Data from the observations which could not be pletured sdequataly in the tabulations was complled in Appendix $D_{2}$ peges $50-53$.

The deviation of the totals obtained while the ehild was on each medication fron those obtained before the girl began drug therapy wero list ed in Appendix 8 , page 54.

Appenda $x$, page 55 , was oonstrueted to eorpare the totals of ech of the four major categorieg of activity occurring during the five observation periods.

Appendix $G$, page 56 , shows the deviation of the totals obtained for each drug from thst obtained while the child was receiving no medieations. Interpretations of the data are discussed in Chapter IV. Chapter V presents the conelusions. 


\section{CHAYTER IV}

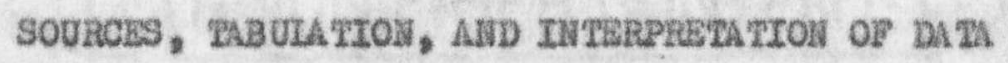

The problen of bypericineats in a ten-year old brain-danaged chald was identlified in Chapter I. Chapter II reviewed the related Isterature and discussed the charecterstles, diagnosis, and education of brain-danaged children. The procedures followed in this investigation to deterrine the relative efricacy of selected drugs upon the physleal activities and the attention span of a brain-danaged ohdld were given in Chapter III. This chapter presents the sourees of dats and cesertbes the tabulation and Interpretation of the Informatton gathered during observations of the ollid's school activities.

A case study' and the chtld's school records were anong the sources of clata used in this investigation. They provided the following informatedion 1

The subjeet of the study was bom February 21,1954 , in Avon Faxic, Morida. It was a forceps birth, and the attending physicians requested x-rays because of severe brulsing of the scalp. Tro of the physictans who saw the x-rays folt that there was no brain-injury despit to the extent of brudsing. One docter, however, esuthoned the prospective parents about the possibility of permanent danage. After a few days the baby was much Improved and the foster parents decided to adopt her.

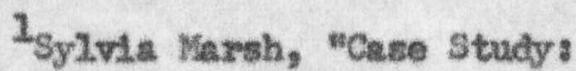
study, Dept. of Education, Andrews university, 1964). (unpubltehed ease 
Very 14 ttle is known about M. C.'s natural parents. The mother was a nineteen-year old Caucasian girl, and it was a full-tern prognancy. The mother is reported to have been mentally giftod and vas graduated as valedietorian of hor high school olass. Because the child was 1llogitinate, the mother "was full of anxilety and under tension during the pregnaney, "1 Also, the baby's mother wanted to put the ohild up for adopthon, whlle the mater nal grandparents wished that she would keep the ohtld so that they could adopt hor.

The child's foster father is a minister and holds a Master's Degree. The foster mother has not yet completed college but 1 s taking coursework. She has boen a proofreeder. Inglish has always been spoken in the home although the parents are Italian. The subject has one brother, also adopted, who 1 s fourteen months younger than she. Fe seens to be developing normally and has wondered, at times, why his sister is different from other children. In the romainder of this stady, the foster parents are referrod to as the ohild's fathor and mother.

The mother roports that the baby was extremely restless and active. At the age of two, she fell from a hospltal crib onto a conerete floor. Though she landed on her head, she did not ory and soeraed not to be serlously hurt. However, the doctor ordered $x$-rays, which revealed no darage. 1. C. attended kindergarten during the afternoons of the school year 1959-1960. The transfor slip from the school lists her as having "medial strabismus" in the right eye, as wosing glasses, and roports "Vision inspection unsatisfactory. ${ }^{2}$ The tranafor also notes that she had been under

\section{Iold., p. 1.}

${ }^{2}$ Elenentary Sehools, Cak Fark, Dulnois, "Transfer Slip," Jume 2, 1960 , (in the files of the school). 
the services of the IIlinols Institute for Juventle Resesreh during 1959. The school beelth appraisal records a towcherwnurse conference in October, 1960, about the "child's non-response to ditrections and enotilonal. alsturbance," "I $^{2}$ An entry on Deceuber 14,2961 , states that the ehild was undergolng testing at the IIIinols Institute for Juvendle Researeh and that muscular co-ordination was below par.

A Juse 19, 1962, letter from the Instil tute to the school pxinolpel reports that the ohild had made inprovement between her vist ts in 1959 and 1961. This letter also states that an ESG record sugeested that the child"s diffleulty was related to "some central nervous system impal maent. ${ }^{2}$ The letter continues: "It was our foeling that the gixl requires a great deal of stability and consistaney from ber anvironient to cospensate for her cur rent instabilsty. She needs support in maintaining control. "w3 The report points out that the child"s "Imature vieusl motor coordination" is revealed

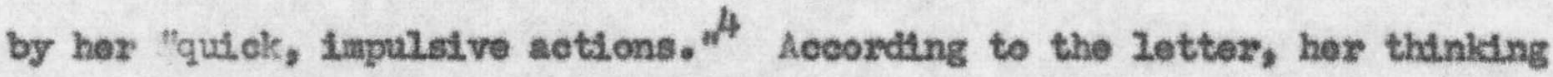
18 "quit te conorste."

The school was urged to observe the activitiles the ohild was able to perform and to hold her to then, but to make allowtances for hor lack of steblilty. The necessity of not allowing her to fake holplessmess in order to gain attention was pointed out.

The letter states that the Institute's Impression of the child is

1wiealth Appraisal," (In the flles of the sehool).

${ }^{2}$ Lotter from the minols Institute for Juvenile Researoh, Crifoago, IIIAnots, Jume 19, 2962, (in the flles of the sehool).

3asc.

"Mald.

5 Dhad. 
that she is "an unstable ginl having an inadequately organised self-concept and sppeared to be confused, but reaching out for stability. She was interosted in improving ber relationships and in reoelving support. " ${ }^{2}$ ApparentIy, the ohild's problea had not got been identifled as brain danage in sph to of the BSal.

In Dotober, 1962, M. C. "s mother mado this corment on the school's "Health Inventory, " "She is very active. ${ }^{2}$

Intelligenes tests' xesults gAve an IQ rangling from 72 to 107 , but examiners have noted that a focusing of attention probably would result in better perfornanee. A September 29, 1963, profile of the Calliformis Iest of Mental Maturity gives a language data IQ of 134 non-language data, 80. Sehool achlevement tests reveal the same thing: that the child performs best in the language arts aroas and poorest in axt thenetle reasoning. The ohtld is a raptd oral reader, rushing through a sentence vith the sane inpulsiveness that she exhibits in her physioal activities. She is able to pronounce surpzisingly difficult words, her furth-grade teacher reports. Sylvia Narsh records that "as a very young chlld she sould spell eomplicated words, and that her father would 'show her off' to visitors by setting her on his knee and having ber quilokly spell long words. " 3

Cbservations of the eldid reveal her very short attention span and seerding compulsion for constant activity. Often she moves about the clessroom, fingering Items as she passes. Though it appears that she is paying absolutaly no attention to the elass aetivities, she ean answer some questions when asked. The other children in the elassroom usually 1 gnore her

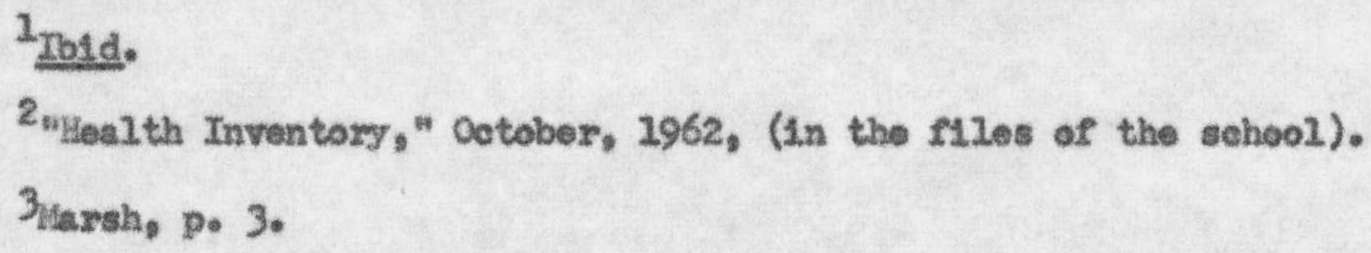

$1_{\text {Ibtd. }}$

2"Health Inventory," October, 1962, (In the f1les of the sehool). 3 Marsh, p. 3. 
when she does something incorrectly or out of 14 ne and aceept her when she participates with them.

The child seems to like musio especially. She follows the rhythr of the rasie with her hands and/or feet. When she flxst jolned the cholr she followed her usual pattern of constant setivity. During practlce she would stand, turn around wh th her ams in the afr, then att down agaln. Other chlldren in the ehoir complained to the director. As a result, the girl was moved from place to place. During one rehesrsal, whlle the cholr was standIng, $X_{\text {. }}$. sat down, leaned back in her ohalr, and elosed her oyes. She remained in that posittion during the rest of the practice sesston. Mfterward, the teacher asked why she had done 1t. Hor mply: "I was tired of sing$\operatorname{lng} \mathrm{n}^{1}$

Having to go to the restroon was used ropestedly as a rosson for leaving practice. Before one session, the muste teacher had a student toacher take the girl to the reatroom. When she wanted to leave curlng row hearsel, the teacher sald no, then reminded her that she had Just been. The chdld has not repeated this tochnique.

Due to her unpredletab114ty, $H_{\text {. C. }}$ was not allowed to sing wd th the cholr for a vesper service. The tescher explained the reason to the ehild. SInce that time, the gril has Improved greatly and Is allowed to sing with the choly for services. After every rehesrsal, she asks the teacher, "Cen I sing with the cholr this Sabbathin ${ }^{2}$ She 18 told that as long as she oontinnes to 1 mprove and to sit still she may sing whenever the choir sings. Harsh reports that the ohtld whas developed a great attraction for N1: 8 s the musie toscher, even to the extent that she told her

Inold, p. 4 .

Ibld.: p. 5 . 
nothor, I whh thes were wy wother and you were the muaic toschQ $20 * n^{2}$

The child ropeatodily asks questlons to whl oh she already knows the

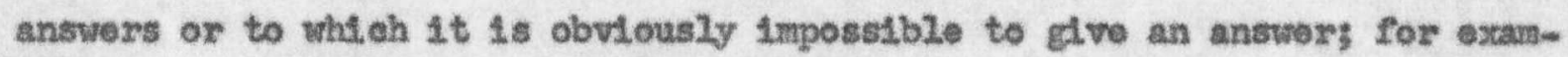
ple, "How doos Carolthe Kennedy spell, her name, "Iyn" or "line?" "Can your

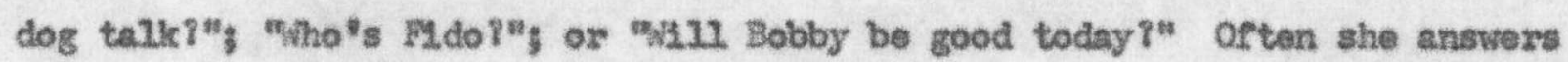
her ow question. Somotires she seems to be pondering a subject audibly.

Teachers report that if someone claps his hands behind her back, the chlld will jump and say, What have $I$ done? What have $I$ done ${ }^{\text {w }}$ and that she Is cruel with animals and has been known to hold a dog so that it dangled from 1 ts lessh and choked.

The ohd Id is dortneering with her playmates and usually is not interested in the activities of her agenates. Often she is unable to comprem hend (her flfth-grade tescher roports) the directions to the ganes balng played. She enfoys children several years younger than she. The ohlid shows awareness of the fact that aho is not sceepted by the world around her for the reasons that other people are. She wonders why she 1 s not liked, why other children frequently do not want to play with ber.

The child's parents seen to be flum with her, especially her father. At one time, advisora told the parents that they were being too easy on her and to "olanp dom" Aftor trying this the father reported that ho could not spank her so much bscause she was incepable of performing the tasics. The parents are trying ts adjuet to the eblid"s abilities and lack of them and to bace expectations on her eapectiles.

In addition to the case study and the sebool records, the parents furnished informstion about the ohtld"s resetions to the different modica- 
tions. On March 11, 1965, the subject's mother supplied the data below: ${ }^{2}$ While the child was on IAbrium, the parents were unable to nottce mach deference in her activities. The drug seemed to have little offect on her and da not caln her down significantly. Interestingly, the chtld herself has several times stated that she thought the "green and yellow" eapo sules "helped me wost."

Prollxdn, one nilligrem two times dally, was discontinued after four days when perents and teacher agreed that the medicetion was acting as an umanted stimulant.

During the flrst throe or four days whlle the girl was talding Mellaril, twenty-flve milligrans three times daliy, she looked droopy-eyed and sleepy, but after about a veok, she overcame the droogy look. When the patient was recelving the rnedication, she slowed down "very, very moh" and "seened improved," However, the psychlatrist told the parents that the drug was too great a depressant.

The Rtalin and Hellemi coublnation reduced hypexicinesis, but the parents "stil1 had feelings whether this was the answer to her probleme" The parents are perplexed by the diffleulty of lenouling how auch to expect of the child. They foel that the girl ahould be able to sccept disappointments wh thout whining and acting meh younger and that this inability to sccept Iittle disappointments is her "biggest problen." One example the mother roported was about a globe. The globe sas a saall, Inexpensive one whlch frequently allpped fron its plastic frane. One time, however, the freme broke, makling it impossible for the parents to repadx 1 t. Though thoy triled to explain why they could not mend the globe, the child reected in ther asual, whiny way." 
The mother also reported about a time when the girl fretted, fussed, and funed, oven in front of company. The chtld had been told that mother would take her to a friend's home in the afternoon, if it were possible. Howover, just before leaving, unexpected company came to cell on the pasm tor's family. This made 1t necessary for the mother to stay heme, and because there was no one else to take the chdld, she had to stay home too. The parents felt that the child should have been ablo to comprehend the reasons for this excoption to their 1 intentions without having to be talked to and spenked before ceasing her whining.

An incident which the girl, seened to understand involved a belloon. While on a trip the ohlld pushed her blowm-up balloon into the front section of the ear soveral times, and received s roprimand because of the danger involved. The perente explained that it made 1 t diffleult for dacdy to drive safeily since the balloon bloeked his vision. The censures seened to have 11ttle offeet, so the rather told $M_{0}$ C. that the next time her balloon came Into the front of the car, he would have to pop 1t. She beeame more careful In her activity, but eventually lot the belloon get in daddy's way. Though he popped 1t, the eluld did not fret or ery. She was quilet, and the mother thought that she "roslized that 1 t was right to pop 1t."

The father seems to have moxe success in controlling the ohlid, but she is "not too fazed by spankings," they report.

While on the Pdtalin and Vellaril combination, the parents noticed that the child made more loud notses and burpod froquently and loudly. They were not sure if the cause was delfberate or if the drug "released" her, and she did not realize how noisy she was being. Sometimes they felt that she burped just to "get a kiek out of 1t."

The following indleates the ohdid's progross: 
During the week of Nerch 1, 1965, the subject studled her Sabbath Sohool lesson alone, though she "played" between her sesslons of stuty. The child is leaming to lanit in the Pothelnder Club. She knowe how to say what to do, and the steps to take, but she gets about halfway through a proceduro and eannot finish, for she drops the needles. The glrl told her grandnother the "next thing to do," but could not mantpulate her own hands to do 1 t.

The ehlld"s parents report that her conversation got better duxing the entirs pertod she was on medications. She st111 repeated questions to which she knew the answers, but gradually conversation is taking the place of the questions. Also, the questions aro becoating more and more "nomal."

The parents concluded that they are "puzzled and unstre as to whethor medication is best for her; they're not convinced, in some ways yes, in some, no."

Another source of date was the ohild's flfth-grade teacher (September, 1964-June, 1965) who gave the following information ${ }^{2}$

From about the lot of January, 1965, the child seexed to make the greatest improvement in her school activitios. The teacher was impreesed particularly with the girl's exthmetie growth. Her attention span was st111 short, but "with a great deal of encouregenent and praise" the pupil would do a whole page of second-grado work by hereelf. The chtld sought constant assurance that she was doing the work correctly. After Inishing one, twe, or three problems, she would consult the teacher in order to have her work ohecked. The teacher reports that the pupll will do ary work that she $1 \mathrm{~s}$ capable of doing by herself if she is pratsed often. The Instruetor says that the girl st111. asks many questions, but 
that they are more nearly like those of a flfti-grade ohild. She foels the quostioning 1 s an attarnt by M. C. to act Iike other poople and to got the attention of otherw. If one does not answer her questlons, even if 1t moans tolling hor that ho does not know, Mo C. looks forlorn and forsalken. The teacher reported that she tried 1 gnoring the questions only once, and that the look upon the girl's face caused her to dectde never to fenore her. A2so, the tescher wants to be sure that the child feels secure in talking with her and does not withdrars.

"It is amasing how good sho is in cortain areas, especially Ingles. She even corrects others. She learns to spoll easliy if she takes the trotble to do so. She reade well, unusually we11, and can pronounce dirfseul.t words, but she does not comunicete her comprohenston." The teacher also says that her handrriting (which had been printing and was practically 11legtble) is defint tely improved, but that $M$. $c$, has not carned over her writing from pemmanship to other work. "Sho 18 using cursive wmiting now, and it is rateh better than hor printing "

The teacher does not excuse the chlld from doling her work, but up until the last grealng period (Maroh), she bad not done enough work to got a real grade. The parents and the teacher had conferred and decided that to get all F's would be ofscouraging, so she was usullly given C"s with all oceastonal B or D. The teacher declared, "I don't knov what she has leamed or what she ean learn." She further explained that while it is difficult to evaluate $\mathrm{M}, \mathrm{C}$. "s progress, it is obvious that the has done better whils on the drugs than she would have done wi thout them.

The toacher reports that the girl is sensitive to pualehaent, even If 1 t is mild. She dislikes having her nawe written on the board when she lenowa it means she is misbohaving. At the beginning of the school year, she 
would take things which did not belong to her. She was told that the teachex would punish her (by having her stand within one gquare on the sidewalk during reess) and also that her parents would be told. This was very alfective and her "taling" has practlealiy oeesed.

Barly in this sehool year tho toacher often had difrlculty getting the gixl to respond to questions. One day the instructor told K. C. that if she would not answer whon called on the teacher could not belp her, and that she should say, "I don"t know," if she did not know an answer. She was also told that sho would have to gtand in the hall, thus belng 1 solated (which she does not like), If she would not answer. The lact that she was not beIng pundshed for not knoving but for not answering was exphssized. This helped immensely, and after the Inttlal incident, the ohild has been responding wueh more.

The teacher feels that the other ohdldren "are very good to hers onIy those in other grades, who do not lmow her, do not rake allowances." The Instruetor also believes that the pupil 1 g getting along better socially. She is sald to be more outgoing and bohaving more naturely, though she is adalttedly still lanature exotLonally. Her comments are beconing more and more "grown-up," aecorthng to the tescher. H. C. has asked whether or not she w11 have a boy friend. She has beeone very "fussy" with har halr and combs it mors herself. The chlid"s mother reports that she wants 1 t to "Look Just mght." At recess, the glxl frequently plays with younger childron. Bometimes she plays alone.

"She's a sweet little girlmwould be hard to deal with othervise. He2 parents are narvelows, "the teacher concluded.

In addition to the fomal observations, the observer hes noted informally the following bits of behavior whitob appear Iminature and purpose- 
less for a ohild alrott eloven years old:

About the 25th of Novenber, 1964, the child was in tho University bookstore, The observer had made a purchase and was paying the cashlor when the cashler renswiced, "Soxethang's wrong with that 11 ttle girl. I can tell 1t by Loolding at her oyes." As the casher rang up the purehase, the eldid rushed over and asked, Where's the belli Where's the bellin she then rushed about the store, seeningly loolcing at everything, yet moving so rap1diy she could not have seen anything clearly. She carge bseic to the cash roglister and said, "I hear a bell. Whore's the belli Moro's the belli" The clerk mede no roply, and the chsld Inuediately moved around the store again. Mftex raking two more efremits about the bookstoro, she $\operatorname{ran}$ up the steps into the groeery store where she began welleing up and cown the afsles. The masager approached her and said, what's enough for today, M

It's time to go hare now," she went out tho door he held open for her. On Deceaber 9, 196h, the patient was observed as she wont home from sohool for lunch. As she passed the grocery store, she stopped at the window and put hox face up to 1t. Hor right hand was weod to shede hor ayes. Aftor spending about forty-five seconds peezing insida, she skipped down to the post offlee where she wallod Inside, tumed around, and cane back to the store window. She stopped and again peerod inside, shacing her eyes wth ber hands, Thos she slcipped down the walle toward howe.

Shortly before Christmas, 1964, the chdid was a menber of the Juntor Cholr whi oh participsted in a Christnes prograx. While on stage she shanged locations trice, and gazed towaxd the colling and wings during the pexfommance (mingling several songs), Only on the chorus of one song atd she look at the ditrector and really sing.

On Fobruasy 20, 1965, the observer approeched two fantlies on a 
sidewalk near Andrews University. The fathers were talling together, followed by the mothers and ehildren. About ten feet behind the fandly group wss the patient. The child seomed unaware of anyone approaching her. She was looking into the sky, even tuming sround, and seldom looked toward the ground. She moved her outstretched arns in a flgure-elght motion. Cently upturned 11ps made a slight smile. Her eyes seened to be foeused on a farm awey object.

The PInal source of data was the tabulations based upon the ehild's activities recorded during the five two-hour obsesvation periods.

Every 1 tea noted during each of the observation's three thirtyminute periods and recess period was conpared with the tabulation guide and a tally mark(s) was placed in the proper colum on the form. Then tallies in each column were totaled. See Appendix C, pages $45-49$.

When eonsidering the dats given on the forns, the reader should be aware of the infornation below:

1. Decasionally, an item was tallied in several different categories, depending upon the child's location at the time of her activity. For example, if the girl was sttting in her seat, flipping through the pages of her book was countod as a "distration, in seat." However, the same activlty (Ilipping through the pages of her book) was recorded as a "distraction, out of seat, "when the child was standing at the tire she perforred the activity.

2. Infrequently, a single movement by the child was classifted under two cetegeries. For example, following the teeoher (for no discomible purpose) was tallied in both the "distraction, out of sest," and "contact with people, M. C. Initiated, with teacher," columns.

3. Opening and elosing of the dosk was considered one distraction. 
4. Conversetion was not countod as a contect although a contact was rado.

5. Fach time the ehlle was distraeted and rotumed to an activity, the activity to which she retumed was counted agsin; for example, working on an arithmetle problen, getting up and playing with the curtain, and ren turning to the problem whe talliod as two "hormal activities, positive, and one "castraction, out of seat."

6. Dach time the ohld went to the restroom, it was counted as a "nomal activity, positive," because the observer was unoble to sscertain her activities while there. However, the number of tripe she made was abnomal, for she sometimes went several. times w thin the two-hour observation pexiocl. Nost of the tine she stayed less than a minute.

Thus, when considering the number of "nomal activities, positive," one should remerber that It includes the return to activities and the "oxtres trips to the restroos.

Data from the observations which could not be pietured adeguately in the tabulations was conptled in Appendix D, pages 50-53.

Wach of the twelve colums of the four drug forns sas comared to the twelve coltums of the form recording the chdld's activities before any medicstions were given. The resalts appess in Appendix $\mathrm{B}$, page 54. A posttive number signifies that more of the activity in quastion occurred while the child was on the drug than when she was on no medication. A negative nubber indicates that fower inoldents of the activity occurred while the patient was on a drug than vhen receiving no mediestion. A zero indicates that there was no difference between the total of Inoldents while the girl. was reeeiving a drug and when she was not. "None" aseane that there was none of the activity recorded while the child was on the partioular modteation. 
However, because there were not any "conversations, other Initiated" while the ehld was recelving no asdication, the numbers on tho drug forns are always positive.

Appendl $x$ I, page 55, Ifsts the four ma jor catogorles and the total number of incidents in each category. The underlined numbers indicate the greatest change from "no drug."

Appendix G, page 56, shows the deviation in the number of sctivithes while on each drug as corpared to the figures obtained while the ollild was on "ho drug." Fositive numbers indicate that more of the activity in questhon oceurred while the child wes on the drug than whon on no medication. Nlegative numbers show that fower Incidents of the activity occurred whlle the pationt was on a drug than then receiving no medieation. A zero indicates that there was no difference between the total number of ineldenta oeeurxing while the child recelved a drug and when she vas not takding a medieation.

To help in interpreting the dsta, bar graphs were construeted, using the information in Appendix $F$.

As oan be noted In Mgure 1, the ohild was distracted two-hundred forty-six thres duxing the two-hour observation recorded before she recetved any modications. A slight reduction in the total nubber of distractions vas recorded whilo Nellaril was being adrinistored, but it is inportant to note that the majority of the distractions observed were quiak eye movements from one object or person to another and took place while the pattent was in her seat, rather then being large aovezents which involved leaving her sest and moving sbout the room, During the time H, C. roceived Prolixin, the distractions dirninished by about ono-half. Whle she was talding LAbrium, the number of distractions wss cut by alnost two-thixds. Duxing the time the 


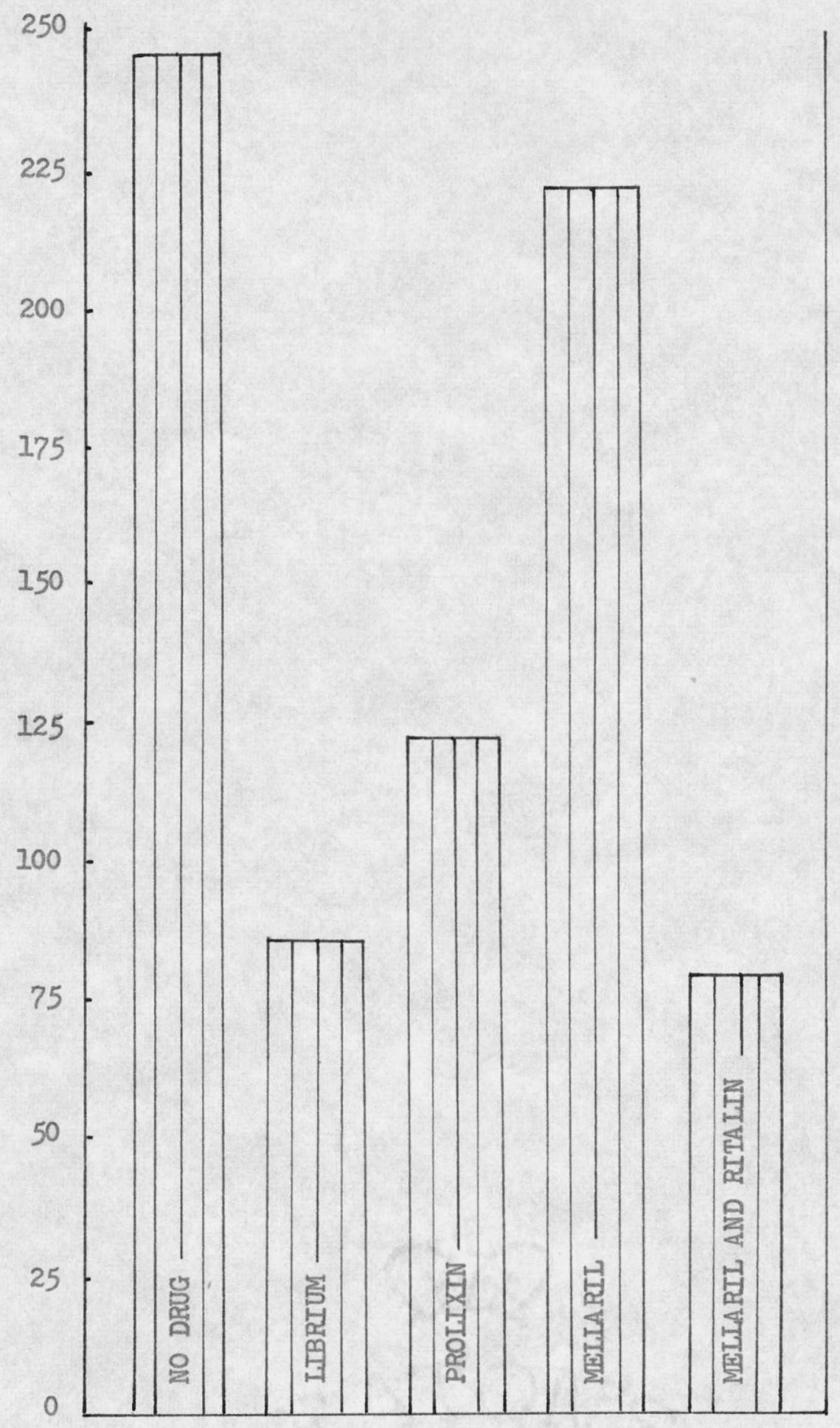

Fig. 1.-. The total number of distractions recorded during five observations of a ten-year old brain-damaged child. 
ohild received the combination of Wellaril and Rtalin, the total number of distractions was reduced to less than one-thdrd of the number recorded dur Ing the perlod before nodieatione vore startod. The data suggeats that the combination of lollaril and litalin was most offective in diminishing distractions,

HIgure 2 shows the total number of contacts with people during the five observation periods (exceluding those made during conversations). Dighteen were recorded while the ohild was recolving no medications. The number of contacts almost doubled while $\mathrm{M}_{0} \mathrm{C}$, was taling IAbrium. During the pexiod of tine that she was on Prolixin, no change in the number of contacts was wade. The girl's contacts with people decreased by one-thind while she was taking lellariz. During the tine she was on the Nollaril and Iftalin combination, the number of contacts was reduced to slightiy less than one-third that recorded while $\mathrm{K}$. C. was talcing no drugs. Although the grestest change in the number of contaets ocourred when M. C. was taking IAbrium, most of these contacts consisted of her following the teacher about the room, which could not be regarded as a nornal or desirable activity. Therafore, it would seos that the Mellaril and Idtalin combination was most sucessful in controlling this setivity.

As IIgure 3 11lustrates, turenty-two conversations were recorded before $\mathrm{K} . \mathrm{C}$. began medications. While the was recelving the Nollaxil and Rtalfin combination, the number of cenversations alnost doubled. The number of conversations inoreased rove than fifty per cent, while the gixl was taidng Frolixin. Conversations were reduced one point during the time the gdrl received Itbritum. While on the Vellaril alone, the number of conversstions was reduoed by about one-thixd. Since the "no drug" observation indicated that the ohlid frequently falled to respond to questions or to participate 


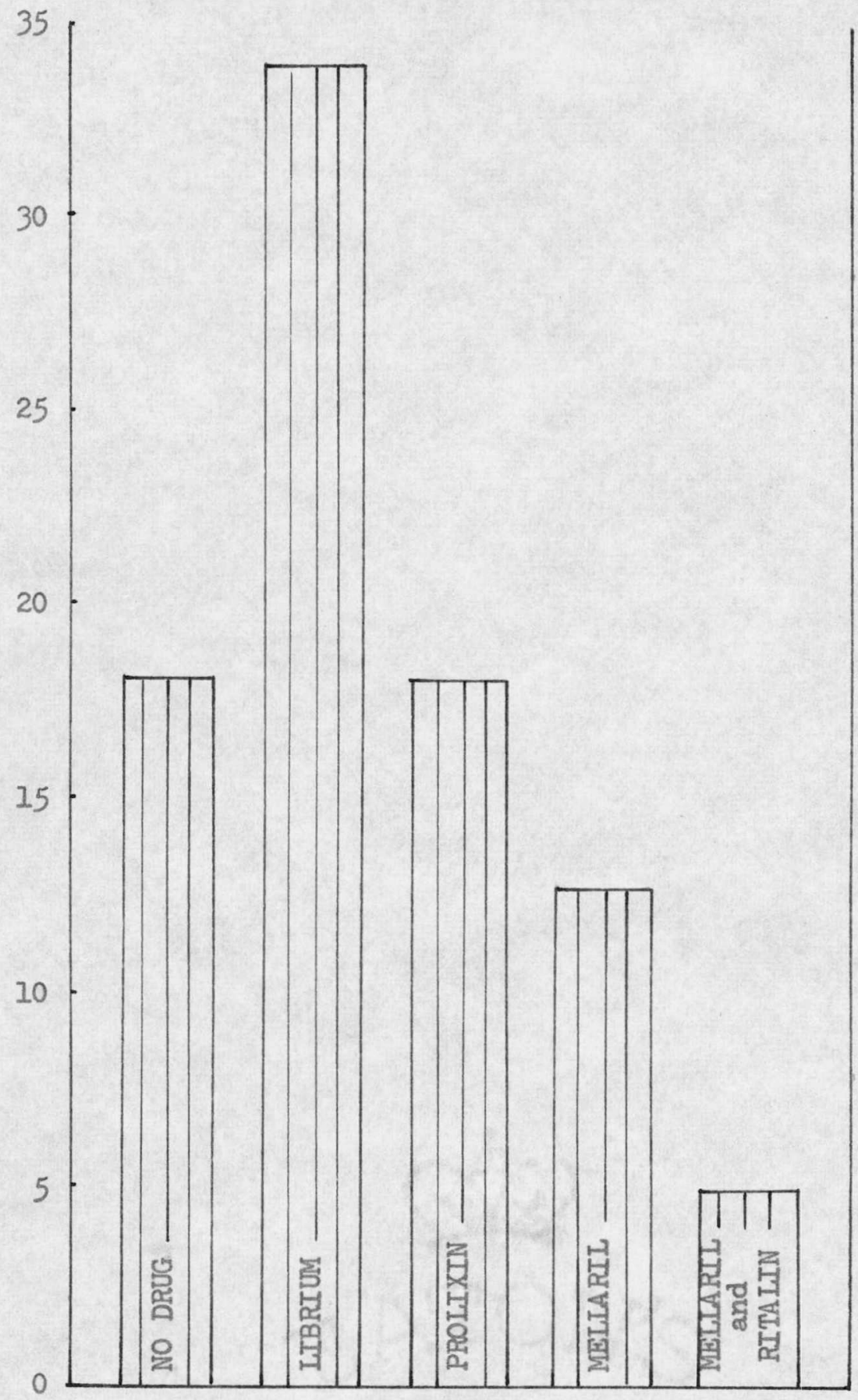

Fig. 2. . The total number of contacts with people recorded during five observations of a ten-year old brain-damaged child. 


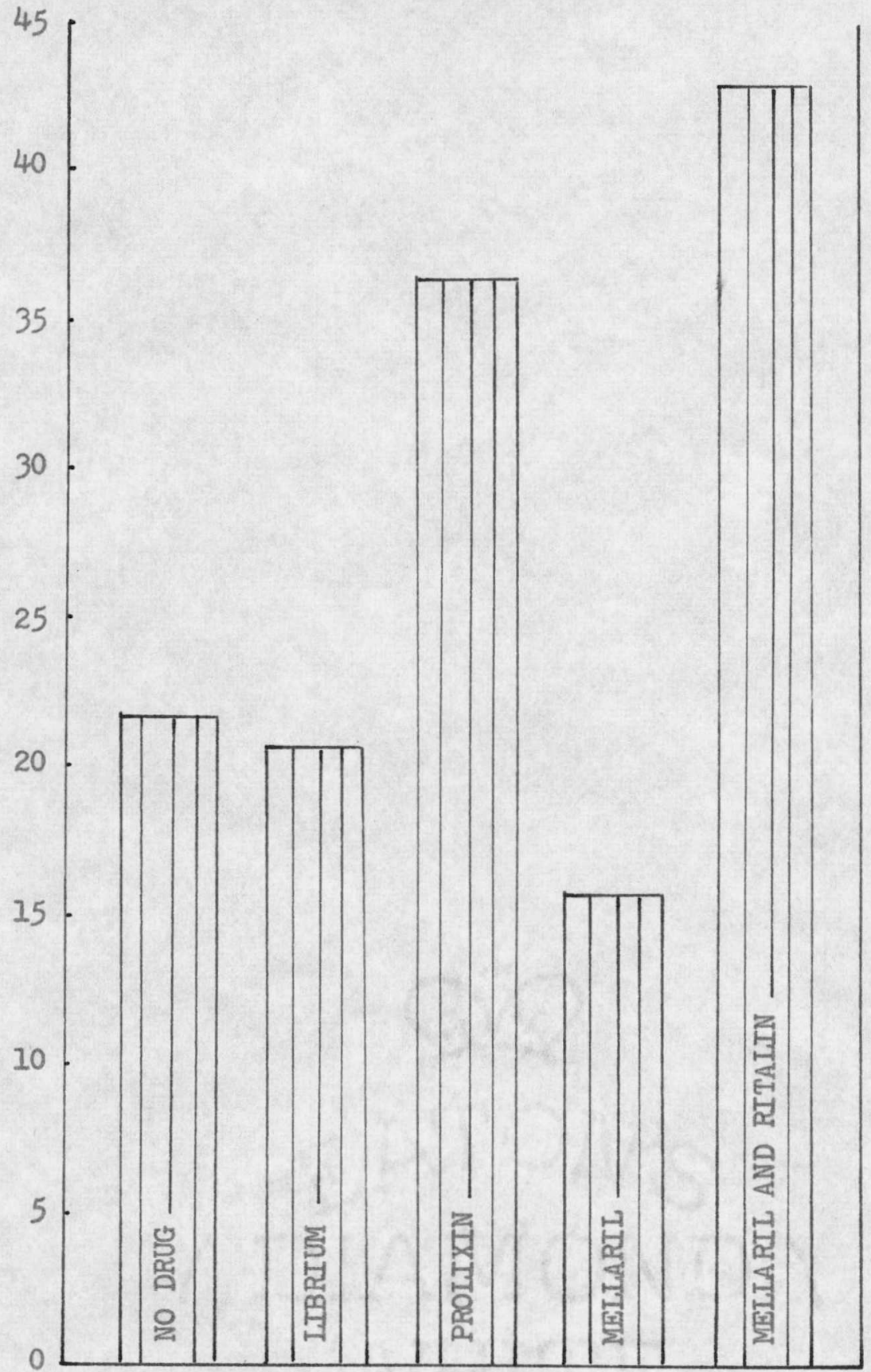

Fig. 3.--The total number of conversations recorded during five observations of a tenyear old brain-damaged child. 
In nornal. conversations with others, it seons correct to conclude that while on the Vollaril and RAtalin conbination the child's conversation and contacts were moxe nomal.

Before If. C. was being given drug tharapy, thirty-five nornal activIthes were recorded (see IIgure 4). It can be seen that the number of desirable setivities inereased while the child was recelving each medicatlon. During the thine the ehild received labrium, the number of norral sctivithes jumped to elmost double the number recorded before she began modications. Mellamil and the Vallaxil and datalin combination differed by only two points; while receiving both, dosirable sctivitlos increased by about threefourths. Though the nusber of sotivities rose by almost one-thdrd during the time $\mathrm{M}_{6} \mathrm{C}$. took Prolixin, this was the smallest ineroase observed while on any drug. 


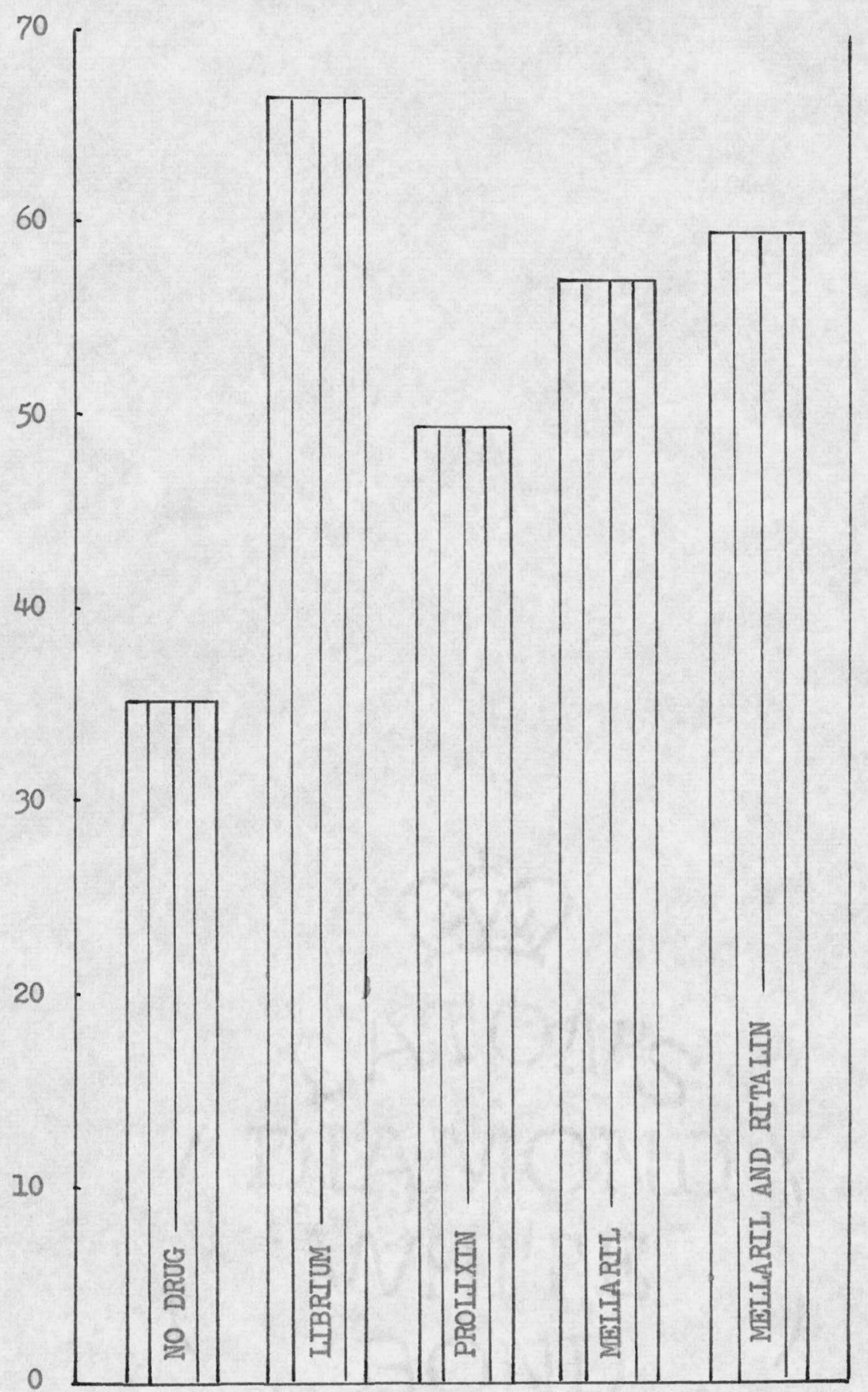

Fig. 4.--The total number of normal activities recorded during five observations of a ten-year old brain-damaged child. 


\section{CHAPTER $V$}

\section{CONCLUSTONS}

The purpose of this study was to deternine the relative effleacy of selected drugs in controlling the physleal activithes and increasing the attention span of a ten-year old brain-danaged child. Relatad studies revealed that drug therspy generaliy had been ineffective in significantiy reducing hyperictnesis and inereasing attention span, though 1roprovenent bsd been noted in some patients.

Because of the child's abnomal behavior (constant and seemingly non-directed activities and a very short attention span), the subject of the study was observed by a psychologlst, a written record of a moming"s sehool aetivities was made, and a case study was prepared. Upon the basis of the data gathered, the child wes referred to a psychiatmst. Drug therspy was begun and the present study was ade to deteralne the relative effectiveness of the selected drags in improving the ohdld's behavlor.

According to the dats gathered, the greatest desirable changes in three of the four major areas consldered appeared whtle the ehild was taking a combination of Mellard 1 and Rtalin. Distractions were neduced to less than one-third of the number recorded before drug therapy wss begun. Contacts with people diminished to slightly less than one-thind the number observed before redications were given. This was interpreted as being desirable since the child's previous contacts consisted malniy of her following the teacher as she moved about the classroon. Whale the subject was recelv- 
Ing the Nellarli and Ritalin combination, the number of conversations almost doubled. This was considered desirable since the ohild previously had not participated in nornal conversations with others.

The grestest number of noral activitiles was rocorded duming the period of time in whlch the ehlld recelved IAbrium. The Ineresse resehed to almost tulce the number recorded before the child began taking medications. The Mellaril and Filin comblnation ranked second highest with an Inerease of about seventy-five per cent over the number of activities noted during the observation before dxug therapy wes began.

Thus, accorling to the date gathered in this study, in the case of one ten-year old brain-danaged ehild (1) the use of each drug resulted in improvenent in one or more areas of the chtld"s behavlor, (2) some of the drugs, while belng effective in particular aress, appeared to have undesirable effects, and (3) the combination of Mellarli and Fitalin was most satiafactory in controlling byperactivity and increasing attention span.

Further research is needed to deternine whether the discoveries made are applieable only to this ohild or if the medications investlgated will be holpful in controlling hyperkinesls and increasing attention apan in other brain-damaged children. 
APFEUDIXES 


\section{APPENDIX A}

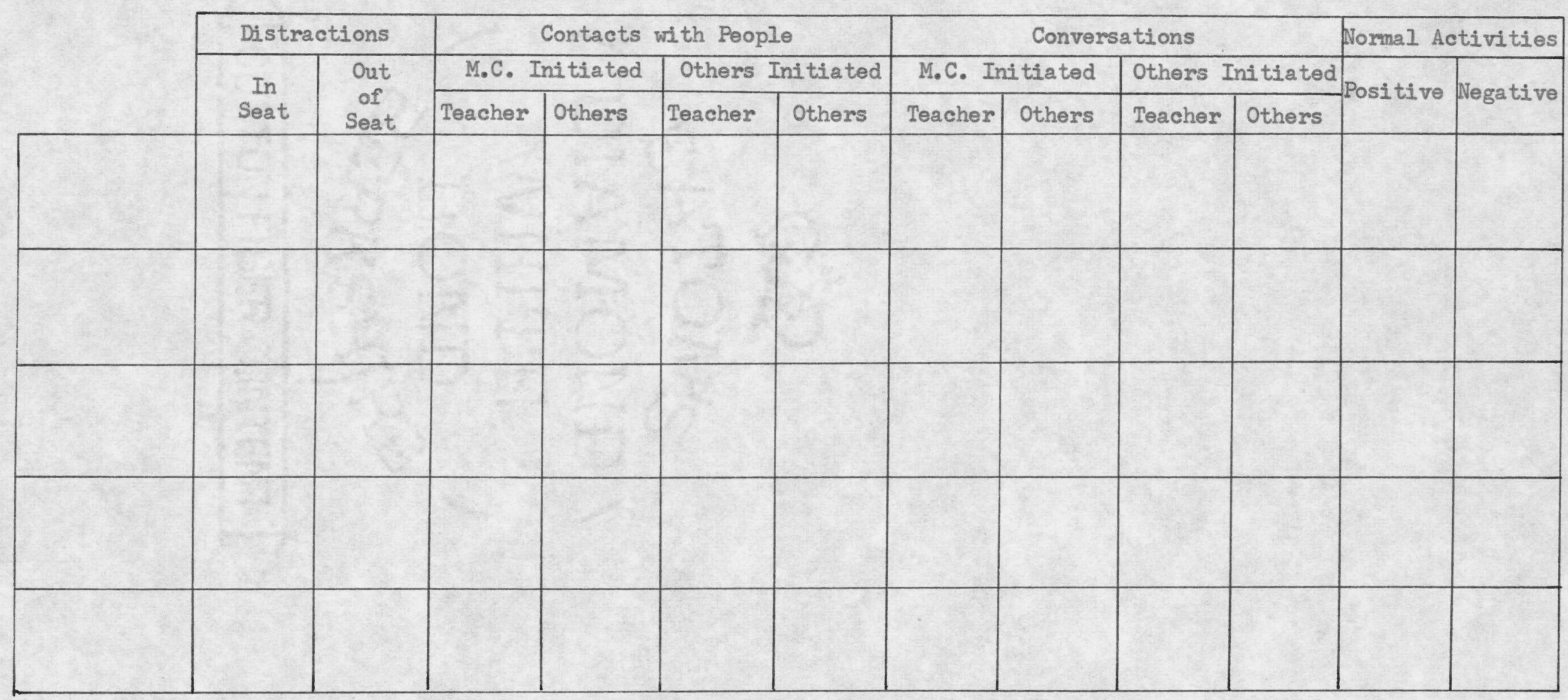


APPEADIX B

TABULAซTON GUD:

13ting hands-cistractlon, In sest or out of sest, depending upon vitere the chlid was at the thine the bohavler occurred.

Cherring on book-distraction, in seat.

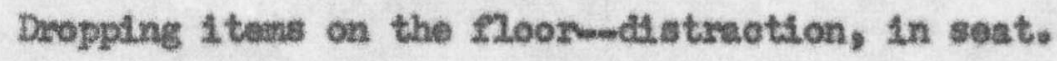

nlpping pages-oldstractlon, in or out of sest.

Getting a quick drink-mistraction, out of seat.

Cetting up and sttting down immodis tely-odistrectlon, out of seat.

Grabbing paper from a child-odstraction, in seat.

Holpding push ehild in axingmonoznal activity, post tive.

Heting ohldemoral activity, negative.

Hopping up and cowm-edstraction, out of seat.

Jericing at coat to got it off hangerm-nomal activity, negative.

Jumping jacks (copying acadeny boys)-nornal activity, posittve.

Keeping time to muste with feetmonomal activity, positive.

Knocking lenees together-distruetion, in sest.

Laying 1 tem on desk and watohing it slide off-mistrection, in seat.

Lauing on desk with ams and hoppingendistratetion, out of seat.

Leaving room (without a purpose) -edistraction, out of seat.

Ilstenting to ehlidren practioing song (when patient was supposed to be havIng recoss)-momal activity, negetivo.

Loolding intently at arm (had hurt 1t) -nomomal activity, post tive. 
Looking, whtohing (non-dirscted)-odistraction, in seat or out of seat. Looking through others" things-adrtraction, in seat. Iying in suing-nomal activity, positive. Nouth movements-mastraction, in seat or out of seat. Moving with teachar, following her-distraction, out of seat and contact with people, $K_{0}$ C. Initiated, wilh teacher. Wlot getting in line and moving with other ehildren-mistraction, out of seat.

Opening and closing desk-distraction, in seat. Participating in rogulay classroon activity-nornal activity, positive. Playing in snow with feetmenoral, activity, positive. Playing on bars, on slech-nomal activity, positive. Feying with hair-distraction, in seat. Maying with hands, bicyole motion-mdistrettion, out of sest. Playing whth moving curtain (alix vent caused it to move)-distraction, out of sest.

Pulling up knee socks-nomal activity, positive. Fulling up skirt (from bottom, not pulling it up to keop 1t up)-mistraction, out of seat.

Putting objects in mouth-distraetion, in seet. Quickly ralsing and lowering hand (wL thout purpose)-distraction, in sest. Repidly moving feet up and down while sitting in seatmdistraction, in seat. Rearranging material on deak-distraotion, in seat. Fubbing hand up and down on desk-edistraction, in seat. Danning-norral activity, positive. Shoving on doox-mdistraotion, out of seat. Sitting in swings-mornal activity, positive. 
Standing, alone--distraction, out of seat.

Standing by teachorm-distraction, out of seat; contact with peoplo, M. C. Int tisted, with toscher.

Straighteming bieyclo she had nearly lonocked over-nomal activity, positíve.

Swingting alono-norral activity, postitive.

Swinging on polo-normal activity, positive.

Telleing to self-mistraction, in seat or out of seat.

Taking 1ten from another's desk-distraction, in seat or out of seat. Tapping on teacher-distraction, out of soat; contact with people, M. C. in1tiated, wh th teacher.

Trying to take sulng from another-nomal activity, negative; contact with people, K. C. Initiated, with others.

Trying to turn on TV-cilstrection, out of seat.

Tristing in swings-momal activity, positive.

Walling from and returning to seat (wthout purpose)-mdistraction, out of seat.

Walling, meandoringly--d4straction, out of seat.

Watehing observor-distraction, in seat.

Wiggling whole body while in sest, bounce-1ike-mistrection, in seat. Writting on paper (not assignment)-distraction, in seat. 
APPENDIX C

NO MEDICATION

\begin{tabular}{|c|c|c|c|c|c|c|c|c|c|c|c|c|}
\hline & \multicolumn{2}{|c|}{ Distractions } & \multicolumn{4}{|c|}{ Contacts with People } & \multicolumn{4}{|c|}{ Conversations } & \multicolumn{2}{|c|}{ Normal Activities } \\
\hline & \multirow{2}{*}{$\begin{array}{l}\text { In } \\
\text { Seat }\end{array}$} & \multirow{2}{*}{$\begin{array}{c}\text { Out } \\
\text { of } \\
\text { Seat }\end{array}$} & \multicolumn{2}{|c|}{ M.C. Initiated } & \multicolumn{2}{|c|}{ Others Initiated } & \multicolumn{2}{|c|}{ M.C. Initiated } & \multicolumn{2}{|c|}{ Others Initiated } & \multirow{2}{*}{ Positive } & \multirow{2}{*}{ Negative } \\
\hline & & & Teacher & Others & Teacher & Others & Teacher & Others & Teacher & Others & & \\
\hline $\begin{array}{c}\text { Classroom } \\
10: 30-11: 00\end{array}$ & 61 & 45 & & $?$ & & & & 3 & 3 & & 6 & \\
\hline $\begin{array}{c}\text { Classroom } \\
11: 00-11: 30\end{array}$ & 43 & 30 & & 2 & 2 & & 4 & & 2 & & 7 & 3 \\
\hline $\begin{array}{c}\text { Classroom } \\
11: 30-12: 00\end{array}$ & 18 & 49 & 2 & 2 & $y=$ & 2 & 1 & 3 & 2 & & 2 & 1 \\
\hline Recess & & & & 1 & & & 1 & 3 & & & 16 & \\
\hline Totals & 122 & 124 & 2 & 12 & 2 & 2 & 6 & 9 & 7 & & 31 & 4 \\
\hline
\end{tabular}


IIBRTUM

\begin{tabular}{|c|c|c|c|c|c|c|c|c|c|c|c|c|}
\hline & \multicolumn{2}{|c|}{ Distractions } & \multicolumn{4}{|c|}{ Contacts with People } & \multicolumn{4}{|c|}{ Conversations } & \multicolumn{2}{|c|}{ Jormal Activities } \\
\hline & \multirow{2}{*}{ In } & \multirow{2}{*}{$\begin{array}{l}\text { Out } \\
\text { of } \\
\text { Seat }\end{array}$} & \multicolumn{2}{|c|}{ M.C. Initiated } & \multicolumn{2}{|c|}{ Others Initiated } & \multicolumn{2}{|c|}{ M.C. Initiated } & \multicolumn{2}{|c|}{ Others Initiated } & \multirow{2}{*}{ Positive } & \multirow{2}{*}{ Negative } \\
\hline & & & Teacher & Others & Teacher & Others & Teacher & Others & Teacher & Others & & \\
\hline $\begin{array}{c}\text { Classroom } \\
10: 30-11: 00\end{array}$ & 28 & 7 & 2 & 12 & & & 3 & & & & 8 & 1 \\
\hline $\begin{array}{l}\text { Classroom } \\
11: 00-11: 30\end{array}$ & 16 & 11 & 4 & 1 & & & 3 & & 4 & 1 & 9 & 1 \\
\hline $\begin{array}{c}\text { Classroom } \\
11: 30-12: 00\end{array}$ & 17 & 8 & 3 & & 8 & & 7 & & & & 16 & 1 \\
\hline Recess & & & & 12 & & & 1 & 1 & & 1 & 26 & 5 \\
\hline Totals & 61 & 26 & 9 & 25 & & & 14 & 1 & 4 & 2 & 59 & 8 \\
\hline
\end{tabular}




\section{PROLIXIN}

\begin{tabular}{|c|c|c|c|c|c|c|c|c|c|c|c|c|}
\hline & \multicolumn{2}{|c|}{ Distractions } & \multicolumn{4}{|c|}{ Contacts with People } & \multicolumn{4}{|c|}{ Conversations } & \multicolumn{2}{|c|}{ Normal Activities } \\
\hline & \multirow{2}{*}{$\begin{array}{l}\text { In } \\
\text { Seat }\end{array}$} & \multirow{2}{*}{$\begin{array}{l}\text { Out } \\
\text { of } \\
\text { Seat }\end{array}$} & \multicolumn{2}{|c|}{ M.C. Initiated } & \multicolumn{2}{|c|}{ Others Initiated } & \multicolumn{2}{|c|}{ M.C. Initiated } & \multicolumn{2}{|c|}{ Others Initiated } & \multirow{2}{*}{ Positive } & \multirow{2}{*}{ Negative } \\
\hline & & & Teacher & Others & Teacher & Others & Teacher & Others & Teacher & Others & & \\
\hline $\begin{array}{c}\text { Classroom } \\
10: 30-11: 00\end{array}$ & 28 & 7 & 2 & 12 & & & 3 & & & & 8 & 1 \\
\hline $\begin{array}{c}\text { Classroom } \\
11: 00-11: 30\end{array}$ & 16 & 11 & 4 & 1 & & & 3 & & 4 & 1 & 9 & 1 \\
\hline $\begin{array}{c}\text { Classroom } \\
11: 30-12: 00\end{array}$ & 17 & 8 & 3 & & & & 7 & & & & 16 & 1 \\
\hline Recess & & & & 12 & & & 1 & 1 & & 1 & 26 & 5 \\
\hline Totals & 61 & 26 & 9 & 25 & & & 14 & 1 & 4 & 2 & 59 & 8 \\
\hline
\end{tabular}


MELIARIL

\begin{tabular}{|c|c|c|c|c|c|c|c|c|c|c|c|c|}
\hline & \multicolumn{2}{|c|}{ Distractions } & \multicolumn{4}{|c|}{ Contacts with People } & \multicolumn{4}{|c|}{ Conversations } & \multicolumn{2}{|c|}{ Normal Activities } \\
\hline & \multirow{2}{*}{$\begin{array}{c}\text { In } \\
\text { Seat }\end{array}$} & \multirow{2}{*}{$\begin{array}{c}\text { Out } \\
\text { of } \\
\text { Seat }\end{array}$} & \multicolumn{2}{|c|}{ M.C. Initiated } & \multicolumn{2}{|c|}{ Others Initiated } & \multicolumn{2}{|c|}{ M.C. Initiated } & \multicolumn{2}{|c|}{ Other Initiated } & \multirow{2}{*}{ Positive } & \multirow{2}{*}{ Negative } \\
\hline & & & Teacher & Others & Teacher & Others & Teacher & Others & Teacher & Others & & \\
\hline $\begin{array}{l}\text { Classroom } \\
10: 30-11: 00\end{array}$ & 92 & 16 & 1 & 1 & & & & & & & 4 & \\
\hline $\begin{array}{c}\text { Classroom } \\
11: 00-11: 30\end{array}$ & 71 & 10 & & 1 & & & 4 & 2 & 3 & & 8 & 3 \\
\hline $\begin{array}{c}\text { Classroom } \\
11: 30-12: 00\end{array}$ & 24 & 11 & 1 & & & & 1 & 3 & & 1 & 24 & 2 \\
\hline Recess & & & & 3 & 1 & 4 & & 2 & & & 14 & 2 \\
\hline Totals & 187 & 37 & 2 & 5 & 1 & 4 & 5 & 7 & 3 & 1 & 50 & 7 \\
\hline
\end{tabular}


MELLARIL AND RITALTN

\begin{tabular}{|c|c|c|c|c|c|c|c|c|c|c|c|c|}
\hline & \multicolumn{2}{|c|}{ Distractions } & \multicolumn{4}{|c|}{ Contacts with People } & \multicolumn{4}{|c|}{ Conversations } & \multicolumn{2}{|c|}{ Normal Activities } \\
\hline & \multirow{2}{*}{$\begin{array}{l}\text { In } \\
\text { Seat }\end{array}$} & \multirow{2}{*}{$\begin{array}{l}\text { Out } \\
\text { of } \\
\text { Seat }\end{array}$} & \multicolumn{2}{|c|}{ M.C. Initiated } & \multicolumn{2}{|c|}{ Others Initiated } & \multicolumn{2}{|c|}{ M.C. Initiated } & \multicolumn{2}{|c|}{ Others Initiated } & \multirow{2}{*}{ Positive } & \multirow{2}{*}{ Negative } \\
\hline & & & Teacher & Others & Teacher & Others & Teacher & Others & Teacher & Others & & \\
\hline $\begin{array}{l}\text { Classroom } \\
10: 30-11: 00\end{array}$ & 33 & 5 & & & & & 2 & 6 & & 2 & 16 & \\
\hline $\begin{array}{c}\text { Classroom } \\
11: 00-11: 30\end{array}$ & 3 & 2 & & & & & & 2 & & 2 & 13 & \\
\hline $\begin{array}{l}\text { Classroom } \\
11: 30-12: 00\end{array}$ & 9 & 26 & 1 & 3 & & & 6 & 14 & 3 & 2 & 13 & \\
\hline Recess & & & & 1 & & & & 3 & 1 & & 4 & 13 \\
\hline Totals & 45 & 33 & 1 & 4 & & & 8 & 25 & 4 & 6 & 46 & 13 \\
\hline
\end{tabular}




\section{APPENDTX D}

\section{NON-WABULATED DATA}

\section{No Medilestions}

Before the child was on any modication, very fow activities in whioh she engaged were orlented toward sohoolwork. She seened oblivious to the rast of the roon, yet her attention to little things, such as pieces of lint, showed that she was observing more of her surroundings than one would suspect from soeing her darting moverents and superfluous activities. Also, she was able to answer some questions, such as those about a story to which an obsarver thought that she had peid absolutely no attention. The obild roamed about the room, taking round-about routes to a destination. often she opened and elosed ber desk without a reason. No one thing recelved her attention for very long. The girl frequently ignored questions which were asked of her. If she wade any comuent, it usualiy was 1 molevant.

The pupil would also volunteer to do a partloular thing, such as demonstrate an arithatic problem, but when ealled upon, would ignore, refuse, or be unable to do the work (often, the activity was one in which she had already successfully engaged, the teacher reported).

\section{Librum}

While recelving the drug, Labrium, the patient continued to behave In wuch the same way as she had done previously, the wost notlceeble excepthon being that she did not Ignore or refuse to answer questions as much as 
she had done before. The child still purposelessly opened and elosed her desk many times, used round-about routes to reach her destinattons, and fingered many objects.

One time the girl very vigorously brushed off har clothing, though she had not solled it. Exoept for participeting in the pre-penatanship exercise (shaiding of axras and hands to limber thean up bofore writting) and the musie elass, the subject's activities were essentially nom-school orlented.

\section{Prolixin}

Throughout all the observations, the ehild showed a desire to be accepted by the other ehlidren as being nownal and engaging in normal activities. This destre becene very noticeable when she felgned taking test. She carrefully numbered her paper, slld dorm the cover sheot, and protended to be thinking of different parts to an answer, counting them on her fingers by putting the thumb to the IIngers in auecesston. At recess the destre for companionship and the desire for a swing to herself seoned to conflict. Six. times the child got in and out of the swing she had to herself. She ran back and forth between the two sets of sulngs, from the set where she could sulng all the time, but alone, to the set where the other girls vere, but where she had to share the swings.

The girl responded to other people by salling or softly lataghing at them. She looked and 11 stened for others" reactlons to hex activities, as when she leafed through papers on the teacherts desk.

At one time during the observation, she spent trenty-one anites in her seat, the maxdmu for 211 the observations made.

\section{Mallaxil}

While on Hellarli the child played more actively with the other 


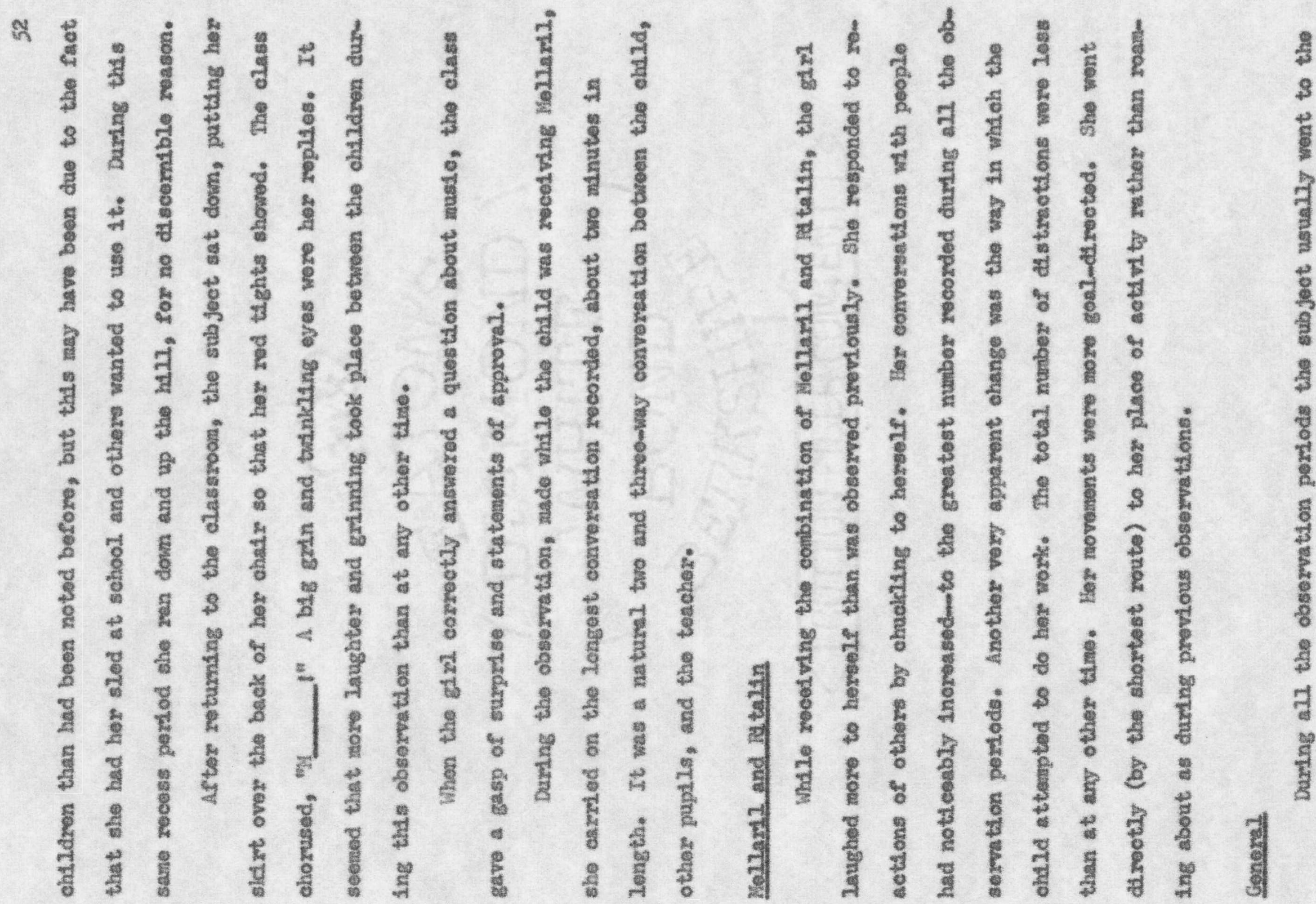


teacher for holp rather than raising her hand. Although a student teacher was sometires in cherge, the regular teacher was alnost always the one sought by M. C.

The observer was aware of at least surface tolerance by the other childron. Host of them were very helpful and did not ridleule or exbarrass the ohtld. The observer could not help but notice, however, that the pathent was considered odd and was not desirod for a compenion, though she wanted the approval of the children and seldom difeetly bothered a chlld. 
APPENDIX E

\begin{tabular}{|c|c|c|c|c|c|c|c|c|c|c|c|c|}
\hline & \multicolumn{2}{|c|}{ Distractions } & \multicolumn{4}{|c|}{ Contacts with People } & \multicolumn{4}{|c|}{ Conversations } & \multicolumn{2}{|c|}{ Normal Activities } \\
\hline & \multirow{2}{*}{ In $_{\text {Seat }}$} & \multirow{2}{*}{$\begin{array}{l}\text { Out } \\
\text { of } \\
\text { Seat }\end{array}$} & \multicolumn{2}{|c|}{ M.C. Initiated } & \multicolumn{2}{|c|}{ Others Initiated } & \multicolumn{2}{|c|}{ M.C. Initiated } & \multicolumn{2}{|c|}{ Others Initiated } & \multirow{2}{*}{ Positive } & \multirow{2}{*}{ Negative } \\
\hline & & & Teacher & Others & Teacher & Others & Teacher & Others & Teacher & Others & & \\
\hline $\begin{array}{l}\text { No Drug } \\
\text { (Base-total } \\
\text { number of each } \\
\text { petivity which } \\
\text { occurred) }\end{array}$ & 122 & 124 & 2 & 12 & 2 & 2 & 6 & 9 & 7 & 0 & 31 & 4 \\
\hline Librium & -61 & -28 & +7 & +13 & & & +8 & -8 & -3 & +2 & +28 & +4 \\
\hline Prolixin & -30 & -92 & +2 & -6 & none & -1 & +13 & 0 & -3 & +5 & +12 & +2 \\
\hline Mellaril & +65 & -97 & 0 & -7 & -1 & $+\underline{2}$ & -1 & -2 & $-\underline{4}$ & +1 & +19 & +3 \\
\hline $\begin{array}{c}\text { Mellaril } \\
\text { and } \\
\text { Ritalin }\end{array}$ & -27 & -91 & -1 & -8 & none & none & +2 & +16 & -3 & +6 & +15 & +9 \\
\hline
\end{tabular}

Note: The underlined numbers indicate the greatest change in each characteristic. 
APPENDIX F

\begin{tabular}{|c|c|c|c|c|}
\hline $\begin{array}{c}\text { Drug } \\
\text { Names }\end{array}$ & Distractions & $\begin{array}{r}\text { Contacts } \\
\text { with } \\
\text { People }\end{array}$ & Conversations & $\begin{array}{c}\text { Normal } \\
\text { Activities }\end{array}$ \\
\hline No Drug & 246 & 18 & 22 & 35 \\
\hline Iibrium & 87 & 34 & 21 & 67 \\
\hline Prolixin & 124 & 18 & 37 & 49 \\
\hline Mellaril & 224 & 12 & 16 & 57 \\
\hline $\begin{array}{c}\text { Mellaril } \\
\text { and } \\
\text { Ritalin }\end{array}$ & 28 & 5 & 43 & 59 \\
\hline
\end{tabular}

Note: The underlined numbers indicate the greatest change from "No Drug" in each column. 
APPENDIX G

\begin{tabular}{|c|c|c|c|c|}
\hline Drug Names & Distractions & $\begin{array}{c}\text { Contacts with } \\
\text { People }\end{array}$ & Conversations & $\begin{array}{c}\text { Normal } \\
\text { Activities }\end{array}$ \\
\hline $\begin{array}{c}\text { (Base-total number of } \\
\text { each activity which } \\
\text { occurred) }\end{array}$ & 246 & 18 & 22 & 35 \\
\hline Iibrium & -159 & +16 & -1 & +32 \\
\hline Prolixin & -122 & 0 & +15 & +14 \\
\hline $\begin{array}{c}\text { Mellaril } \\
\text { Mellaril } \\
\text { and }\end{array}$ & -22 & -6 & -6 & +22 \\
\hline
\end{tabular}

Note: Plus or minus indicates the direction of deviation from "No Drug."

Underlined number indicates greatest change from "No Drug." 


\section{BIBITOGR PEY}

\section{Books}

Baker, Marry J. Introduction to Erceentional Chtidron, 3d ed. Now York: Macandilan Company, 1959.

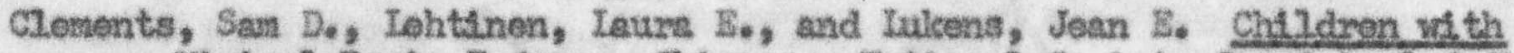
Minimal. Bratn Inturg. Chseago: Wational Soctety for Crippled Chal. dron and Achits, 1964.

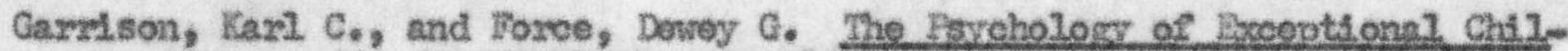
dinen. 3d od. New Iork: Ronald Eress Company, 1939.

D8. Frances La, and Ares, Louise Bates. Ghild Behavlor. Roprinted from

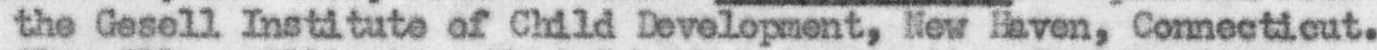
Gien IIyn, Mitnols: West Suburban Association for the othor Child, n.d.

Kirk, Baruel A, and Wolnor, Bluma B. (ods.). Behavtor Basearoh on Broenthonal Children. Hew Yoxis: The Councti for bxooptional ChIdren, Ifationa? Ecueation Assoctation, 1963.

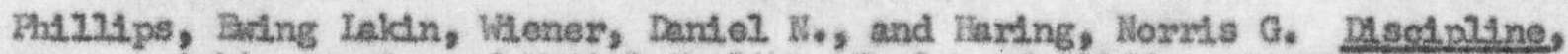

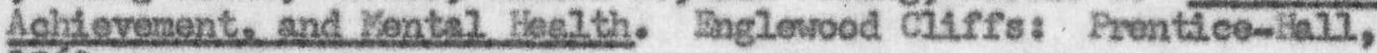
1960.

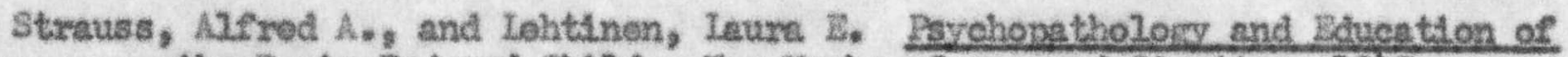
the Bratn-Intuxed ChI1d. Bew Yoxk: Gruno and Stratton, 1947.

Porlodicals

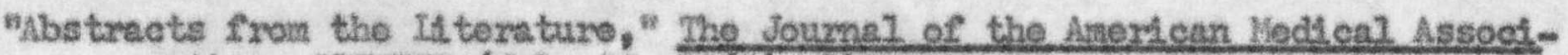
attion, crxxuII ( Jaly 23, 1960), 1403.

Bach, Jerome H., and Keoson, Wultan, "Gramulocyte Suppresston with Thior 1dartine tydrochioridotn, "Tho Journal of the Arextean Medacel Assoelation, CLXXTII (Jine 18, 1960), 793-794.

Barbe, Walter 3. Woeting the lieeds of Irreoptional Children," Echuention, LXXXrV (Apmi1, 1964), 476m479. 
Batterman, Pobort C., Nouratoff, George Je, and Kaufan, Jerome E. "Coaparats re Treatnent of the Psyohoneurotic Reactive-type Andiety State with Buphenasine and Chloxdiazepoxdide," Blolorton? Abstrects, RIV (SoptemberwCotobor, 1964), 6261.

Beek, Joen. "Wental Mraclos for Brain-Injurod ChtIdren," Chleseo Jxtbume Maranine, Septomber 13, 2964, po. 26-44.

Clements, San D., and Fetors, John B. MAnimal. Brain Dysfunctione in tho

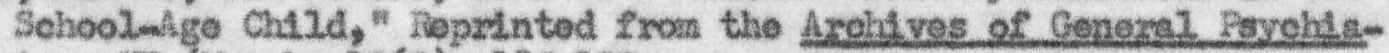
tres, VI (Werch, 1963), 185-197.

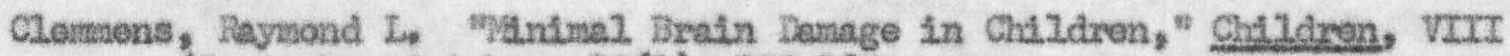
(Septerben-oetober, 1961), $179-183$.

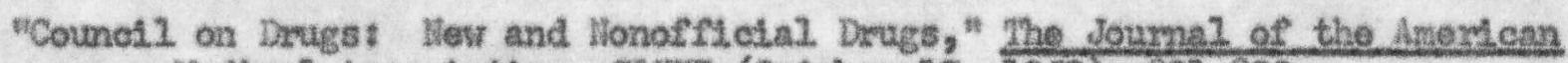
Berteal Assoolation, CLTXI (Cotober 17, 1959), 091-093.

"Creopins, Crawling" Therapy Mostoros Boy's Nomal. IAfe," Arkansas Demoext, Decorber 22, 1964, p. 1.

Darr111, Fred s. "Double-31ind Ivaluation of Methylphentdate (Rtalin) Fy-

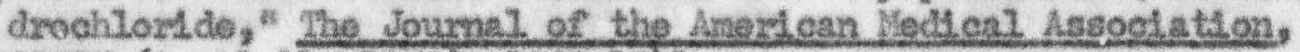

CLxtX (Apr11 27, 1959), 2739-1741.

Dcyle, P. J. "The Organte Hyperidnette Syndrome, Journal of Sohool. Dealth. ExtrI (Cotober, 1962), 299-306.

"Druge Dvaluated by the Counct2, on Drugs," The Jouxnal of the Amerlean Yed4c21 Associatton, CLXXXV (JuIy 27, 1963), 298.

nxuge Evaluated by the Counct on Druge Duxing 1960," The Joumal of the

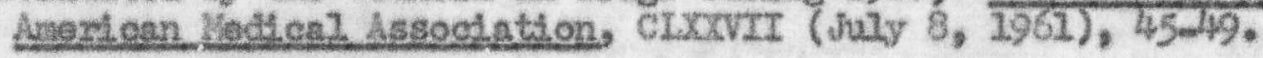

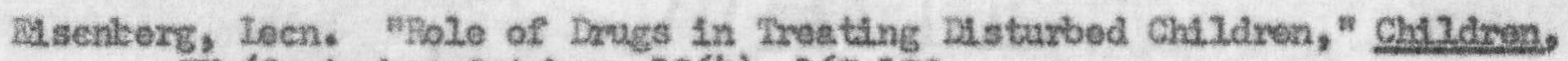
XV (Septemberw0etober; 1964 ), 167-173.

Ferguson, John T., et al. Wiethylphentdate (Pdtatin) Hydrochlorddo Parenteral Solution;" The Joumal of the Amexican Yodica? Assoctatton, GLIII (Doseriber 1, 2956), 1303-1304.

"Forelgn Lettors," The Journal of the Amexican Nedicel Agsoolation, CLxxג. (Fobruazy 6, 1960), 539-595.

Kinross-Wright, John. Fiewex Phonothlaghine Drugs in Treatrant of Nervous

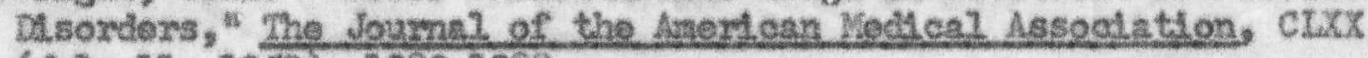
(July 11, 1959), 1283-1298.

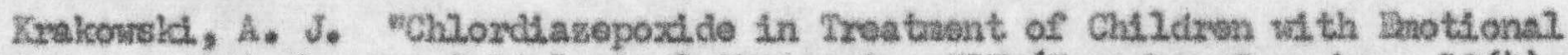
Di.e tarbances," Biolorien. Abstrects, XIV (lioverber-Decomber, 1964), 8245. 
Krupp, George Re, and Schwartzberg, Bernard. "The Brain-injured Child: A Challenge to Social Workers," Social Casework, XIII (Fobruary, 1960), $63-69$.

Naisel, Albert Q. "Hope for Brain-Injured Children," Reader's Digest, LXXXVV (October, 1964), 135-140.

Matson, Virginia F. "Miracles Can Fappen to Brain-Danaged Children," Parents' Magazine, XXXVI (August, 1961), 48-49, 114-116.

Maller, Nandeen. "Teaching an Emotionelly-Disturbed, Brain-Injured Child," Reading Teacher, XVII (March, 1964), 460-465.

Morrow, Leura s. "Huphenazine in the Iong-Term Treatment of Nonhospitalized Psychiatric Patients," Biologioal Abstracts, XIV (September-October, 1964), 6596.

"New Drugs and Developments in Therapeutics," The Journal of the Americen Modical Association, CLXXVII (July 29, 1961), 245-246.

Roth, Iloyd J., and Barlow, Charles F. "Drugs in the Brain," Science, CXXXIV (JuIy 7, 1961), 22-31.

Watson, C. Wesley, Bowker, Reinette, and Calish, Claire. "Mafect of ChlorLazepoxide on Epilepti.c Selizures." Biological Abstracts, XIV (Novernbor-December, 1964), 7266.

"Wonder Drugs and Menta.I Disorders," Consumer Reports, XXX (August, 1955), $386-389$.

Ziporyn, Marvin, and Stoner, Harold E. "The Use of Mluphenazine Fydrochloride (Prolixin) in Acute Functional Psychoses, "Biological Abstracts, XIV (September-October, 1964), 6914.

\section{Other Sources}

Mlementary Schools, Oak Park, Dlinois, "Iransfer Slip," June 2, 1960, (in the flles of the school).

"Health Appraisal," (in the files of the school).

"Fiealth Inventory," dated October, 1962, (in the files of the school).

Inlinois Institute for Juvenile Research, Ietter to the school principal, dated June 19, 1962.

Information Sheet on Mellaril, Sandoz Pharmaceuticals, Division of Sandoz, Incorporated, Hanover, New Jersey, July 12, 1963.

Interview with the flfth-grade teacher, March 10, 1965. 
Interview w1 th the Mother, March 11, 1965.

Marsh, Sylvia. "Case Study: _ _ Unpublished ease study, Dopartanent of Education, Andrews Lniveraity, 1964. (Iyped.)

$(27-3045$ 